\title{
ANALISIS KINERJA DISTRIBUSI INSTALASI PENGOLAHAN AIR (IPA) (STUDI KASUS IPA DAERAH PEJOMPONGAN I)
}

\author{
S. WALUYO WR ${ }^{1)}$ RIRIS ${ }^{2)}$ \\ 1) Program Studi Teknik Sipil \\ Fakultas Teknik \\ Universitas Muhammadaiyah Tangerang \\ Jl. Perintis Kemerdekaan I/33, Cikokol Kota Tangerang \\ http://www.umt.ac.id \\ waluyo_sidik@yahoo.com \\ 2) Program Pascasarjana Magister Teknik Sipil \\ Universitas Gunadarma \\ Jl. Salemba Raya, Jakarta Pusat \\ http://www.gunadarma.ac.id \\ oweriris@yahoo.com
}

\begin{abstract}
ABSTRAK
Air adalah zat yang paling penting dalam kehidupan setelah udara, 3/4 bagian tubuh kita terdiri dari air dan tidak seorangpun dapat bertahan hidup lebih dari 4-5 hari tanpa minum air. Di samping itu air juga dipergunakan untuk memasak, mencuci, mandi dan membersihkan kotoran yang ada di sekitar rumah,untuk keperluan industri, pertanian, pemadam kebakaran, tempat rekreasi, transportasi.

Peningkatan jumlah penduduk di tiap tahunnya mengakibatkan kebutuhan air bersih yang digunakan tiap hari semakin meningkat. Tentu saja peningkatan kebutuhan air bersih tersebut mempengaruhi ketersediaan air bersih yang berhasil diolah. Untuk memenuhi kebutuhan air bersih tersebut, perlu dilakukan evaluasi dan analisis terhadap kondisi instalasi pengolahan air yang saat ini dengan meninjau aspek teknis dan finansial dari instalasi tersebut. Aspek teknik yang ditinjau adalah evaluasi kondisi unit-unit pengolahan kondisi eksisting terhadap standar kriteriadesain, analisis kapasitas unit-unit pengolahan terhadap kebutuhan air hingga 20 tahun mendatang $\left(\mathrm{Q}_{20 \mathrm{th}}\right)$ serta evaluasi kualitas air produksi terhadap standar Peraturan Menteri Kesehatan RI No. 492/Menkes/Per/IV/2010

Sedangkan aspek finansial yang ditinjau adalah analisis pengaruh biaya produksi dan penjualan air bersih terhadap laba kotor IPA Pejompongan I. Variabel yang dikendalikan adalah biaya produksi seperti biaya sumber air bersih dan biaya pengolahan air bersih, biaya penjualan air bersih dan laba kotor. Dalam upaya meningkatkan kualitas pelayanan, diperlukan suatu evaluasi terhadap instalasi pengolahan air agar masalah tersebut dapat dikendalikan.

Tujuan dari penelitian ini adalah untuk menganalisis kondisi eksisting IPA Pejompongan I ditinjau dari aspek teknis, seperti: Memproyeksikan pertumbuhan penduduk di wilayah pelayanan IPA hingga 20 tahun, mengetahui kebutuhan air bersih, menganalisis kapasitas unit instalasi pengolahan air berdasarkan kriteria desain, mengevaluasi kapasitas unit pengolahan air, mengevaluasi kinerja air baku sesuai standar PP 82/2001, mengevaluasi kinerja air hasil produksi sesuai standar Peraturan Menteri Kesehatan RI No. 492/Menkes/Per/IV/2010, dan mengetahui seberapa besar pengaruh biaya sumber air bersih, biaya pengolahan air dan hasil penjualan air bersih terhadap laba kotor yang diterima oleh IPA PJ.
\end{abstract}

Kata kunci: Analisis kinerja, kebutuhan air bersih, biaya, pertambahan penduduk 


\section{BAB 2 \\ TINJAUAN PUSTAKA}

\subsection{PROYEKSI KEBUTUHAN AIR}

\subsubsection{Proyeksi Pertumbuhan Penduduk}

Dalammerencanakaninstalasipengolahan air minumdiperlukaninformasimengenaikebutuhan air minum di wilayahperencanaan.Kebutuhan air minumsangatditentukanolehkondisiwilayahperencana an,

pertambahanjumlahpendudukdantingkatsosialekonom ipenduduk yang mempengaruhipolapemakaian air.

Prediksijumlahpenduduk di masa yang akandatingsangatpentingdalammemperhitungkanjuml ahkebutuhan air minum di masa yang akandatang. Prediksiini

didasarkanpadalajuperkembangankotadankecenderu ngannya, arahan tatagunalahansertaketersediaanlahanuntukmenampun gperkembanganjumlahpenduduk.

Denganmemperhatikanlajuperkembanganju mlahpendudukmasalampau,

makametodestatistikmerupakanmetode yang paling mendekatiuntukmemperkirakanjumlahpenduduk di masamendatang. Ada beberapametode yang dapatdigunakanuntukmenganalisaperkembanganjuml ahpenduduk di masamendatangyaitu :

a. Metode Arithmatik

Metodeinibiasanyadisebutjugadengan rata-rata

hilang.Metodeinidigunakanapabila data berkalamenunjukkanjumlahpenambaha $\mathrm{n}$ yang relatifsamatiaptahun. Hal initerjadipadakotadenganluaswilayah yang kecil, tingkatpertumbuhanekonomikotarendah danperkembangankotatidakterlalupesat (jujubandung, 2012). Rumusmetodeiniadalah :

$$
\begin{aligned}
& K a=\frac{P_{2}-P_{1}}{T_{2}-T_{1}} \\
& P_{n}=P_{o}+K a\left(T_{n}-T_{o}\right)
\end{aligned}
$$

Dimana :

$\mathrm{P}_{\mathrm{n}}=$ Jumlah penduduk pada tahun ke-n $\mathrm{P}_{\mathrm{o}}=$ Jumlah penduduk pada tahun dasar

$\mathrm{T}_{\mathrm{n}}=$ Tahun ke-n

$\mathrm{T}_{\mathrm{o}}=$ Tahun dasar

$\mathrm{Ka}=$ Konstanta Arithamtik

$\mathrm{P}_{1}=$ Jumlah penduduk yang diketahui pada tahun pertama

$\mathrm{P}_{2}=$ Jumlah penduduk yang diketahui pada tahun terakhir
$\mathrm{T}_{1}=$ Tahun pertama yang diketahui

$\mathrm{T}_{2}=$ Tahun terakhir yang diketahui

b. Metode Geometrik

Untukkeperluanproyeksipenduduk, metodeinidigunakanbila data jumlahpendudukmenunjukkanpeningkat an yang pesatdariwaktukewaktu (jujubandung, 2012). Rumus yang dipergunakan dalam metode geometrik adalah :

$$
\mathrm{Pn}=\mathrm{Po}(1+\mathrm{r})^{\mathrm{n}}
$$

\section{Dimana :}

$\mathrm{Pn}=$ Jumlah penduduk pada tahun ke-n Po $=$ Jumlah penduduk pada tahun dasar

$\mathrm{r} \quad=$ Laju pertumbuhan penduduk

$\mathrm{n} \quad=$ Jumlah interval waktu

c. Metode Least Square

Rumus yang digunakan dalam metode least square adalah :

$$
\begin{aligned}
Y & =a+b \cdot X \\
a & =\frac{\left(\sum Y * \sum X^{2}\right)-\left(\sum X * \sum X Y\right)}{\left(n * \sum X^{2}\right)-\left(\sum X\right)^{2}} \\
b & =\frac{\left(n * \sum X Y\right)-\left(\sum X * \sum Y\right)}{\left(n * \sum X^{2}\right)-\left(\sum X\right)^{2}}
\end{aligned}
$$

Dimana :

$\mathrm{Y}=$ Nilai variabel berdasarkan garis

regresi

$\mathrm{X}=$ Variabel independent

$\mathrm{a}=$ konstanta

$\mathrm{b} \quad=$ koefisien arah regresi linear

Agar perkiraan jumlah penduduk pada masa yang akan datang mendekati kebenarannya, maka dipilih salah satu cara yang tepat melalui metode korelasi sebagai dasar pemilihan, dimana data penduduk aktual dihubungkan dengan perhitungan ketiga metode tersebut. Bilamana nilai $\mathrm{r}$ (koefisien korelasi) yang mendekati nilai 1 (satu), berarti hubungan terjadi hubungan yang sangat kuat atau mendekati kebenaran.

Adapun rumus koefisien korelasi adalah sebagai berikut :

$$
r_{x y}=\frac{\sum x y}{\sqrt{\left(\sum x^{2}\right)\left(\sum y^{2}\right)}}
$$


Untuk memberikan interprestasi koefisien korelasi dapat dilihat pada tabel dibawah ini :

Tabel2.1 Pedoman Untuk Memberikan Interpretasi

Koefisien Korelasi

\begin{tabular}{|l|l|}
\hline Interval Koefisien & Tingkat Hubungan \\
\hline $0,00-0,199$ & Sangat Rendah \\
\hline $0,20-0,399$ & Rendah \\
\hline $0,40-0,599$ & Sedang \\
\hline $0,60-0,799$ & Kuat \\
\hline $0,8-1,00$ & Sangat Kuat \\
\hline
\end{tabular}

Sumber : Metode Penelitian Administrasi,

Sugiono, 2007

\subsubsection{Kebutuhan Air Bersih Domestik Dan Non Domestik}

Air bersih adalah air yang digunakan untuk keperluan sehari - hari yang kualitasnya memenuhi syarat kesehatan dan dapat diminum apabila telah dimasak. Umumnya kebutuhan air untuk berbagai macam tujuan dapat dibagi menjadi :

1. Kebutuhan Domestik

Kebutuhan domestik meliputi :

1. Sambungan Rumah ialah meliputi sambungan langsung dari perpipaan tersier melalui meteran air ke rumah pelanggan

2. Hidran Umum ialah sarana pelayanan air bersih yang digunakan secara bersama-sama (komunal), berupa tangki penampungan baik sambungan langsung dari perpipaan maupun diisi melalui mobil tangki.

2. Kebutuhan Non Domestik

1. Kebutuhan institusi,yaitu kebutuhan kebutuhan air untuk sekolah, rumah sakit, gedung-gedung pemerintah,tempat ibadah dan lain-lain.

2. Kebutuhan industri dan niaga, yaitu kebutuhan untuk industri berupa industri kecil, menengah dan besar,sama halnya dengan niaga seperti toko-toko, swalayan, supermarket dan lain-lain.

\subsection{SISTEM PENGOLAHAN AIR}

Tujuan dari sistem pengolahan air minum yaitu untuk mengolah sumber air baku menjadi airminum yang sesuai dengan standar kualitas, kuantitas, dan kontinuitas. Tingkat pengolahan air minum ini tergantung pada karakteristik sumber air baku yang digunakan. Sumber air baku berasal dari air permukaan dan air tanah. Air permukaan cenderung memiliki tingkat kekeruhan yang cukup tinggi dan adanya kemungkinan kontaminasi oleh mikroba yang lebih besar. Untuk pengolahan sumber air baku yang berasal dari air permukaan ini,unit filtrasi hampir selalu diperlukan. Sedangkan air tanah memiliki kecenderungan untuk tidak terkontaminasi dan adanya padatan tersuspensi yang lebih sedikit.

Secara umum,proses pengolahan air minum dengan sumber air baku yang berasal dari air permukaan dapat digambarkan sebagai berikut :

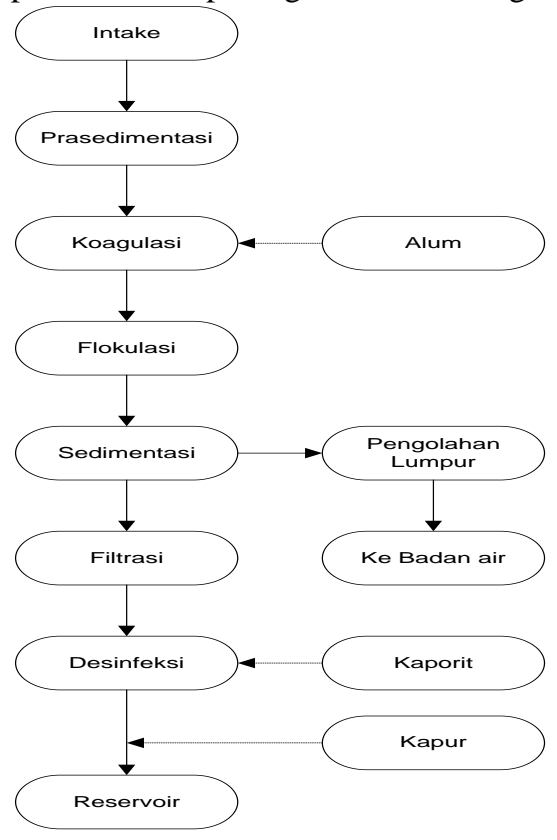

Gambar 2.1 Skema Pengolahan Air Minum

\subsection{UNIT INSTALASI PENGOLAHAN AIR 2.3.1 Koagulasi}

Koagulasi didefinisikan sebagai destabilisasi muatan pada koloid dan partikel tersuspensi, termasuk bakteri dan virus oleh suatu koagulan. Pengadukan cepat (flash mixing) merupakan bagian terintegrasi dari proses ini. Secara umum proses koagulasi berfungsi untuk :

- Mengurangi kekeruhan akibat adanya partikel koloid anorganik maupun organik di dalam air

- Mengurangi warna yang diakibatkn oleh partikel koloid di dalam air

- Mengurangi bakteri-bakteri patogen dalam partikel koloid, algae, dan organisme plankton lain

- Mengurangi rasa dan bau yang diakibatkan oleh partikel koloid dalam air.

Pengadukan cepat (Rapid Mixing) 
Tipe alat yang biasanya digunakan untuk memperoleh intensitas pengadukan adan gradien kecepatan yang tepat bisa diklasifikasikan sebagai berikut :

a. Pengaduk Mekanis

Pengadukan secara mekanis adalah metode yang palingumum digunakan karena metodeini dapat diandalkan, sangat efektif,dan fleksibel pada pengoperasiannya. Biasanya pengadukan cepat menggunakan turbine impeller, paddle impeller atau propeller untuk menghasilkan turbulensi (Reynolds, 1982). Pengadukan tipe ini pun tidak terpengaruh oleh variasin debit dan memiliki headloss yang sangat kecil.

b. Pengaduk Pneumatis

Tipe ini mempergunakan tangki dan peralatan aerasi yang hampir mirip dengan peralatan yang digunakan pada proses lumpur aktif. Rentang waktudetensi dan gradien kecepatan yang digunakan sama dengan pengadukan secara mekanis. Pengadukan tipe ini tidak terpengaruh oleh variasi debit memiliki headloss yang relatif kecil.

c. Pengaduk Hidrolis

Pengadukan secara hidrolis dapat dilakukan dengan beberapa metode, antara lain dengan menggunakan baffle basins,weir, flume dan loncatan hidrolis. Pengadukan jenis ini memanfaatkan energi dalam aliran yang menghasilkan nilai gradien kecepatan $(\mathrm{G})$ yang tinggi,serta tidakperlu mengimpor peralatan,mudah dioperasikan,dan pemeliharaan yang minimal (Schulz/Okun,1984). Tetapi metodde ini memiliki kekurangan antara lain tidak bisa disesuaikan dengan keadaan dan aplikasinya sangat terbatas pada debit yang spesifik.

\begin{tabular}{l} 
Tabel 2.3 Kriteria Desain Unit Koagulasi \\
\begin{tabular}{|l|l|l|l|l|}
\hline $\begin{array}{l}\text { Paramet } \\
\text { er }\end{array}$ & \multicolumn{5}{c|}{ Sumber } \\
\hline & $\begin{array}{l}\text { Qasi } \\
\text { m,et } \\
\text { al } \\
\text { (2000 } \\
\text { ) }\end{array}$ & $\begin{array}{l}\text { SNI } \\
6774 \\
2008\end{array}$ & $\begin{array}{l}\text { Delpho } \\
\text { s, et al } \\
\text { (AWW } \\
\text { A } \\
2004)\end{array}$ & $\begin{array}{l}\text { Damasetia } \\
\text { wan (2001) }\end{array}$ \\
\hline $\begin{array}{l}\text { Dosis } \\
\text { kosgula } \\
\text { n (ppm) }\end{array}$ & $\begin{array}{l}20 \\
\text { ppm }\end{array}$ & & & $25-40$ ppm \\
\hline $\begin{array}{l}\text { Gradien } \\
\text { kecepata } \\
\text { n (1/dtk) }\end{array}$ & $100-$ & $>750$ & $150-$ & $200-1000$ \\
\hline $\begin{array}{l}\text { Kondisi } \\
\text { aliran }\end{array}$ & 1000 & & 300 & \\
\hline $\begin{array}{l}\text { Waktu } \\
\text { detensi } \\
\text { (menit) }\end{array}$ & $\begin{array}{l}10 \\
\text { detik } \\
\text { menit }\end{array}$ & $\begin{array}{l}1-5 \\
\text { menit }\end{array}$ & $\begin{array}{l}30 \\
\text { detik }\end{array}$ & $<1$ menit \\
\hline
\end{tabular} \\
Sumber : Qasim, SNI 2008, Dsplhos, Darmasetiawan \\
\hline
\end{tabular}

\subsubsection{Flokulasi}

Flokulasiadalahtahappengadukanlambat yang mengikuti unit pengadukcepat.Tujuandari proses iniadalahuntukmempercepatlajutumbukanpartikel, halinimenyebabkanaglomerasidaripartikelkoloidterde stbalisasissecaraelektronikakepadaukuran yang terendapkandantersaring.

\subsubsection{Sedimentasi}

Sedimentasiadalahpemisahanpadatandancair andenganmenggunakanpengendapansecaragravitasiu ntukmemisahkanpartikeltersuspensi yang terdapatdalamcairantersebut (Reynolds, 1982). Proses inisangatumumdigunakanpadainstalasipengolahan air minum.

Aplikasiutamadarisedimentasipadainstalasipengolaha $\mathrm{n}$ air minumadalah :

1. Pengendapanawaldari air permukaansebelumpengolahanoleh unit saringanpasircepat

2. Pengendapan air yang telahmelalui proses

koagulasidanflokulasipadainstalasi yang menggunakansystempelunakan air olehkapur-soda

3. Pengendapan air yang telahmelalui proses

koagulasidanflokulasisebelummemasuk i unit saringanpasircepat

4. Pengendapan air padainstalasipemisahanbesidanmangan

\subsubsection{Filtrasi}

Filtrasi adalah proses pemisahan padatan dan larutan,dimana larutan tersebut dilewatan melalui suatu media berpori atau materi berpori lainnya untuk menyisihkan partikel tersuspensi yang sangat halus sebanyak mungkin. Proses ini digunakan pada instalasi pengolahan air minum untuk menyaring air yang telah dikoagulasi dan diendapkan untuk menghasilkan air minum dengan kualitas yang baik.

\section{Media Penyaring}

Berdasarkan jenis media penyaring yang digunakan,saringan pasir cepat ini dapat dikategorikan menjadi tiga, yaitu :

1. Filter media tunggal

Filter jenis ini mempergunakan satu jenis media saja,biasanya pasir atau batu bara antrasit yang dihancurkan.

2. Filter media ganda

Mempergunakan dua jenis media, biasanya merupakan gabungan dari pasir dan batu bara antrasit yang dihancurkan.

3. Filter multimedia

Filter jenis ini mempergunakan tiga jenis media, biasanya sebagai tambahan dari kedua media yang telah disebutkan diatas diaplikasikan jenis media ketiga yaitu batu akik. 
Saringan pasir dikarakterisasi oleh ukuran efektif dan koefisien keseragaman dari pasir yang digunakan sebagai media filtrasi. Sebagian besar saringan pasir cept memiliki pasir dengan ukuran efektif antara 0,35 sampai $0,50 \mathrm{~mm}$ dan memiliki nilai koefisien keseragaman antara 1,3 sampai 1,7. Karakteristik media filtrasi yang secara umum digunakan dapat dilihat pada tabel dibawah ini :

Tabel 2.4 Karakteristik Media Filter
\begin{tabular}{|l|l|l|l|l|l|}
\hline $\begin{array}{l}\text { Materi } \\
\text { al }\end{array}$ & Bentuk & $\begin{array}{l}\text { Spherit } \\
\text { as }\end{array}$ & $\begin{array}{l}\text { Berat } \\
\text { jenis }\end{array}$ & $\begin{array}{l}\text { Porosit } \\
\text { as }\end{array}$ & $\begin{array}{l}\text { Ukuran } \\
\text { efektif }\end{array}$ \\
\hline & & & relatif & $(\%)$ & Mm \\
\hline $\begin{array}{l}\text { Pasir } \\
\text { Silika }\end{array}$ & $\begin{array}{l}\text { Rounde } \\
\text { d }\end{array}$ & & 0,82 & 42 & $0,4-1,0$ \\
\hline $\begin{array}{l}\text { Pasir } \\
\text { Silika }\end{array}$ & $\begin{array}{l}\text { Angula } \\
\text { r }\end{array}$ & & 0,73 & 53 & $0,4-1,0$ \\
\hline $\begin{array}{l}\text { Pasir } \\
\text { Ottawa }\end{array}$ & $\begin{array}{l}\text { Spheric } \\
\text { al }\end{array}$ & & 0,95 & 40 & $0,4-1,0$ \\
\hline $\begin{array}{l}\text { Kerikil } \\
\text { Silika }\end{array}$ & $\begin{array}{l}\text { Rounde } \\
\text { d }\end{array}$ & & & 40 & $1,0-50$ \\
\hline Gamet & & & & & $0,2-1,4$ \\
\hline $\begin{array}{l}\text { Anthra } \\
\text { sit }\end{array}$ & $\begin{array}{l}\text { Angula } \\
\text { I }\end{array}$ & & 0,72 & 55 & $0,2-1,4$ \\
\hline Plastik & Bisa dipilih sesuai kebutuhan \\
\hline
\end{tabular}
Sumber : Droste, 1997

\section{Media Penyangga}

Media penyangga ini berfungsi sebagai penyangga media penyaring yang diletakkan pada bagian bawah media penyaring tersebut.

\section{Sistem Underdrain}

Sistem underdrain berfungsi untuk mengumpulkan air yang telah difiltrasi oleh media penyaring pada saat saringan pasir cepat beroperasi, sedangkan ketika backwash sistem ini berfungsi untuk mendistribusikan air pencucian.

1. Jumlah air untuk backwash $=1-5 \%$ air terfiltrasi

\begin{tabular}{|l|l|c|c|}
\hline \multirow{2}{*}{ Karakteristik } & \multirow{2}{*}{ Satuan } & \multicolumn{2}{c|}{ Nilai } \\
\cline { 3 - 4 } & & Rentang & Tipikal \\
\hline Antrasit & & & \\
\hline Kedalaman & $\mathrm{m}$ & $45.72-60.96$ & 60.96 \\
\hline Ukuran Efektif & $\mathrm{mm}$ & $0.9-1.1$ & 1.0 \\
\hline Koefisien Keseragaman & & $1.6-1.8$ & 1.7 \\
\hline & & & \\
\hline Pasir & & & \\
\hline Kedalaman & $\mathrm{cm}$ & $15.24-20.32$ & 15.24 \\
\hline Ukuran Efektif & $\mathrm{mm}$ & $0.45-0.55$ & 0.5 \\
\hline Koefisien Keseragaman & & $1.5-1.7$ & 1.6 \\
\hline & & & \\
\hline Laju Filtrasi & $\mathrm{m}^{3} / \mathrm{hr}^{-\mathrm{m}^{2}}$ & $176-469.35$ & 293.34 \\
\hline
\end{tabular}

Selain kriteria desain diatas, ada pula kriteria desain menurut Fair, Geyer dan Okun (1968) :
1. Kecepatan filtrasi
$=5-7,5$
$\mathrm{m} / \mathrm{jam}$
2. Kecepatan backwash
3. Luas permukaan filter
$=15-100 \mathrm{~m} / \mathrm{jam}$
4. Ukuran media :
3. Ukuran efektif
$=10-20 \mathrm{~m}^{2}$

$0,6 \mathrm{~mm}$
4. Koefisien keseragaman

$=1,5$

5. Tebal media penyaring

$=0,45-$ $2 \mathrm{~m}$

6. Tebal media penunjang

$=0,15$ $0,65 \mathrm{~m}$

5. Luas orifice : Luas media

$=(1,5-$ 5) $\times 10^{-3}: 1$

6. Luas lateral : Luas orifice 1

$=2-4:$

7. Luas manifold : luas lateral $=(1,5-3): 1$

8. Diameter orifice $=0,25-$ 0,75 inchi

9. Jarak antara orifice terdekat $=3-12$ inchi

10. Jarak antar pusat lateral terdekat $=3-12$ inchi

11. Kecepatan aliran dalam saluran inlet $=0,6-1,8$ $\mathrm{m} / \mathrm{s}$

12. Kecepatan aliran dalam saluran outlet $=0,9-1,8$ $\mathrm{m} / \mathrm{s}$

13. Kecepatan dalam saluran pencuci $\quad=1,5-$ $3,7 \mathrm{~m} / \mathrm{s}$

14. Kecepatan dalam saluran pembuangan $=1,2-$ $2,5 \mathrm{~m} / \mathrm{s}$

Sedangkan kriteria desain saringan pasir cepat menurut SNI 2008 dapat dilihat pada tabel dibawah ini:

Tabel 2.5 Kriteria Desain Saringan Cepat Sesuai SNI 67742008

\begin{tabular}{|c|c|c|c|c|}
\hline & \multirow[b]{2}{*}{ Unit } & \multicolumn{3}{|c|}{ Jenis Saringan } \\
\hline No & & $\begin{array}{c}\text { Saringan Biasa } \\
\text { (Gravitasi) }\end{array}$ & $\begin{array}{l}\text { Saringan dg Pencucian } \\
\text { Antar Saringan }\end{array}$ & $\begin{array}{c}\text { Saringan } \\
\text { Bertekanan }\end{array}$ \\
\hline 1. & Jumlah bak saringan & $\mathrm{N}=12 \mathrm{Q}^{0.5 *}$ & minimum 5 bak & 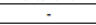 \\
\hline 2. & $\begin{array}{l}\text { Kecepatan penyaringan } \\
(\mathrm{m} / \mathrm{jam})\end{array}$ & $6-11$ & $6-11$ & $12-33$ \\
\hline \multirow[t]{6}{*}{3.} & $\begin{array}{l}\text { Pencucian: } \\
\text { P. Sistem pencucian }\end{array}$ & Tanpaldengan & & Tanpa/dengan \\
\hline & & $\begin{array}{l}\text { blower \& atau } \\
\text { surface wash }\end{array}$ & $\begin{array}{l}\text { Tanpaldengan blower \& } \\
\text { tau surface wash }\end{array}$ & $\begin{array}{l}\text { blower } \& \text { atau } \\
\text { surface wash }\end{array}$ \\
\hline & - Kecepatan (m/jam) & $36-50$ & $36-50$ & $72-198$ \\
\hline & - lama pencucian & $10-15$ & $10-15$ & - \\
\hline & - periode antara dua & $18-24$ & $18-24$ & - \\
\hline & $\begin{array}{l}\text { Pencuclian (jam) } \\
\text { - ekspansi (\%) }\end{array}$ & $30-50$ & $30-50$ & $30-50$ \\
\hline \multirow[t]{7}{*}{4.} & Media pasir: & & & \\
\hline & - tebal $(\mathrm{mm})$ & $\begin{array}{l}300-700 \\
600-700\end{array}$ & $\begin{array}{l}300-700 \\
600-700\end{array}$ & $\begin{array}{l}300-700 \\
600-700\end{array}$ \\
\hline & - media ganda & $300-600$ & $300-600$ & $300-600$ \\
\hline & $\begin{array}{l}- \text { Ukuran efektif,ES } \\
(\mathrm{mm})\end{array}$ & $0,3-0,7$ & $0,3-0,7$ & - \\
\hline & 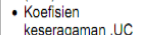 & $1,2-1,4$ & $1,2-1,4$ & $1,2-1,4$ \\
\hline & $\begin{array}{l}\text { - Berat jenis }\left(\mathrm{kg}^{-} / \mathrm{dm}^{3}\right) \\
\text { - Porositas }\end{array}$ & $\begin{array}{l}2,5-2,65 \\
0,4\end{array}$ & $\begin{array}{l}2,5-2,65 \\
0,4\end{array}$ & $\begin{array}{l}2,5-2,65 \\
0,4\end{array}$ \\
\hline & - Kadartas $\mathrm{SiO}_{2}$ & $>95 \%$ & $>95 \%$ & $>95 \%$ \\
\hline
\end{tabular}

\begin{tabular}{|c|c|c|c|c|}
\hline \multirow[b]{2}{*}{ No } & \multirow[b]{2}{*}{ Unit } & \multicolumn{3}{|c|}{ Jenis Saringan } \\
\hline & & $\begin{array}{c}\text { Saringan Biasa } \\
\text { (Gravitasi) }\end{array}$ & $\begin{array}{l}\text { Saringan dg Pencucian } \\
\text { Antar Saringan }\end{array}$ & $\begin{array}{c}\text { Saringan } \\
\text { Bertekanan }\end{array}$ \\
\hline 5. & \begin{tabular}{|l|} 
Media antransit: \\
: tebal $(\mathrm{mm})$ \\
$:$ ES $(\mathrm{mm})$ \\
$: \cup C$ \\
$\cdot$ berat jenis $\left(\mathrm{kg} / \mathrm{dm}^{3}\right)$ \\
$\cdot$ porositas
\end{tabular} & $\begin{array}{c}400-500 \\
1,2-1,8 \\
1,5 \\
1,35 \\
0,5\end{array}$ & $\begin{array}{c}400-500 \\
1,2-1,8 \\
1,5 \\
1,35 \\
0,5\end{array}$ & $\begin{array}{c}400-500 \\
1,2-1,8 \\
1,5 \\
1,35 \\
0,5 \\
\end{array}$ \\
\hline 6. & \begin{tabular}{|l|} 
Filter botom/dasar \\
saringan \\
1)Lapisan penyangga \\
dari atas ke bawah \\
- Kedalaman $(m \mathrm{~m})$ \\
Ukuran butir $(\mathrm{mm})$ \\
$\cdot$ Kedalaman $(\mathrm{mm})$ \\
- Ukuran butit $(\mathrm{mm})$ \\
- Kedalaman $(\mathrm{mm})$ \\
Uduran butir $(\mathrm{mm})$ \\
- Kedalaman $(\mathrm{mm})$ \\
Ukuran butir $(\mathrm{mm})$ \\
\end{tabular} & $\begin{array}{c}80-100 \\
2-5 \\
80-100 \\
5-10 \\
80-100 \\
10-15 \\
80-150 \\
15-30 \\
\end{array}$ & $\begin{array}{c}80-100 \\
2-5 \\
80-100 \\
5-10 \\
80-100 \\
10-15 \\
80-150 \\
15-30\end{array}$ & : \\
\hline & \begin{tabular}{|l|} 
2)Filter Nozel \\
- Lebar Slot nozel (mm) \\
- Prosentase luas slot \\
nozel terhadap luas \\
filter (\%)
\end{tabular} & $\begin{array}{l}<0,5 \\
>4 \%\end{array}$ & $\begin{array}{l}<0,5 \\
>4 \%\end{array}$ & $\begin{array}{l}<0,5 \\
>4 \%\end{array}$ \\
\hline
\end{tabular}




\subsubsection{Desinfektan}

Desinfektan air bersih dilakukan untuk menonaktifkan dan menghilangkan bakteri pathogen untuk memenuhi baku mutu air minum. Khlorin biasanya disuplai dalam bentuk cairan. Ukuran dari wadah khlorin biasanya bergantung pada kuantitas khlorin yang digunakan,teknologi yang dipakai,ketersediaan tempat dan biaya transportasi dan penanganan. Metode yang dapat digunakan untuk mencampur khlorin dengan air adalah metode mekanis dengan penggunaan baffle,hydraulic jump,pompa booster pada saluran.

Kriteria desain menurut Qasim, Motley \& Zhu,2000,pg.491 :

1. Waktu detensi $=10-$ 120 menit

2. Dosis khlor $\quad=0,2-4$ $\mathrm{mg} / \mathrm{L}$

3. Sisa khlor

$$
=0,5-1 \mathrm{mg} / \mathrm{L}
$$

\subsubsection{Reservoir.}

Reservoir terdiri dari dua jenis yaitu ground storage reservoir dan elevated storage reservoir.

Kriteria desain :

1. Jumlah unit atau kompartemen $>2$

2. $\operatorname{Kedalaman}(\mathrm{H})=(3-6) \mathrm{m}$

3. Tinggi jagaan $(\mathrm{Hj})>30 \mathrm{~cm}$

4. Tinggi air minimum $(\mathrm{Hmin})=15 \mathrm{~cm}$

5. Waktu tinggal $(\mathrm{td})>1$ jam

\section{$2.4 \quad$ KUALITAS AIR}

Berdasarkan Peraturan Pemerintah RI No 82 Tahun 2001 tentang pengelolaan kualitas air dan pengendalian pencemaran air pasal 8 disebutkan bahwa klasifikasi mutu air menjadi 4 (empat) kelas, yaitu :

1. Kelas satu ; air yang peruntukkannya dapat digunakan untuk air baku air minum, dan atau peruntukkan lain yang mempersyaratkan mutu air yang sama dengan kegunaan tersebut.

2. Kelas dua ; air yang peruntukkannya dapat digunakan untuk prasarana/sarana rekreasi air, pembudidayaan ikan air tawar, peternakan, air untuk mengairi pertanaman dan lainnya yang mempersyaratkan mutu air yang sama dengan kegunaan tersebut.

3. Kelas tiga ; air yang peruntukkannya dapat digunakan untuk pembudidayaan ikan air tawar, peternakan, air untuk mengairi pertanaman, dan lainnya.

4. Kelas empat ; air yang peruntukkannya dapat digunakan untuk mengairi, pertanaman dan lainnya yang mempersyaratkan mutu air yang sama dengan kegunaan tersebut.

Standar kualitas air minum yang berlaku di Indonesia ditetapkan berdasarkan Peraturan Menteri Kesehatan RI No. 416/MENKES/PER/IX/1990 yang telah diperbaharui dengan Keputusan Menteri Kesehatan RI No. 492/Menkes/Per/IV/2010 Tanggal 19April 2010 tentang Persyaratan Kualitas Air Minum dapat dilihat pada lampiran 1.

\subsection{BIAYA PRODUKSI DAN LAPORAN} LABA RUGI

\section{5.1 Biaya Produksi}

Biaya adalah pengeluaran-pengeluaran atau nilai pengorbanan untuk memperoleh barang atau jasa yang berguna untuk masa yang akan datang atau mempunyai manfaat melebihi satu periode akuntansi.

\subsubsection{Laporan Laba Rugi}

Laporan keuangan merupakan hasil akhir dari suatu proses pencatatan,yang merupakan suaturingkasan dari transaksi-transaksi keuangan yang terjadi selama tahunn buku suatu perusahaan, yang digunakan sebagai alat untuk komunikasi antara data keuangan tersebut. Jadi, laporan laba rugi merupakan suatu ikhtisar pendapatan dan beban yang terjadi mencerminkan hasil pelaksanaan keputusan operasi manajemen dan merupakan kinerja perusahaan selama satu periode akuntansi.

\subsubsection{Laba Kotor}

Laba kotor dipengaruhi oleh faktor-faktor yang menentukan besarnya laba kotor, yaitu :

- Faktor penjualan, yang terdiri atas harga jual satuan dan kuantitas atau volume penjualan. Penyimpangan laba kotor dapat disebabkan perusahaan menjual produk dengan harga jual lebih besar atau jauh lebih kecil daripada harga jual yang direncanakan

- Faktor harga pokok penjualan. Harga pokok penjualan terdiri dari banyak unsur tergantung pada jenis perusahaannya.

\section{5.4 Hubungan Dan Pengaruh Biaya Produksi Terhadap Laba Kotor}

Laba kotor merupakan nilai penjualan setelah dikurangkan dengan harga pokok penjualan. Jadi nilai dan perubahan laba kotor dipengaruhi oleh unsur penjualan dan harga pokok penjualan. Biaya produksi dan penjualan merupakan unsur yang membentuk laba kotor. 
BAB 3

\section{METODE PENELITIAN}

\section{PENDEKATAN PENELITIAN}

Dalam upaya mencapai tujuan penelitian ini,maka diperlukan data yang valid dan reliabel. Data yang didapatkan pada penelitian ini berasal dari observasi langsung ke instalasi, wawancara dan diskusi dengan petugas instalasi departemen Distribution Monitoring Control System PT.XYZ serta pengumpulan data sekunder dari berbagai instansi terkait.

\section{ALUR PENELITIAN}

Alur penelitian ini menggunakan pendekatan studi kasus dengan berbagai metode statistik didalamnya dan bantuan program SPSS versi 17. Alur penelitian dapat dilihat pada Gambar 3.1.

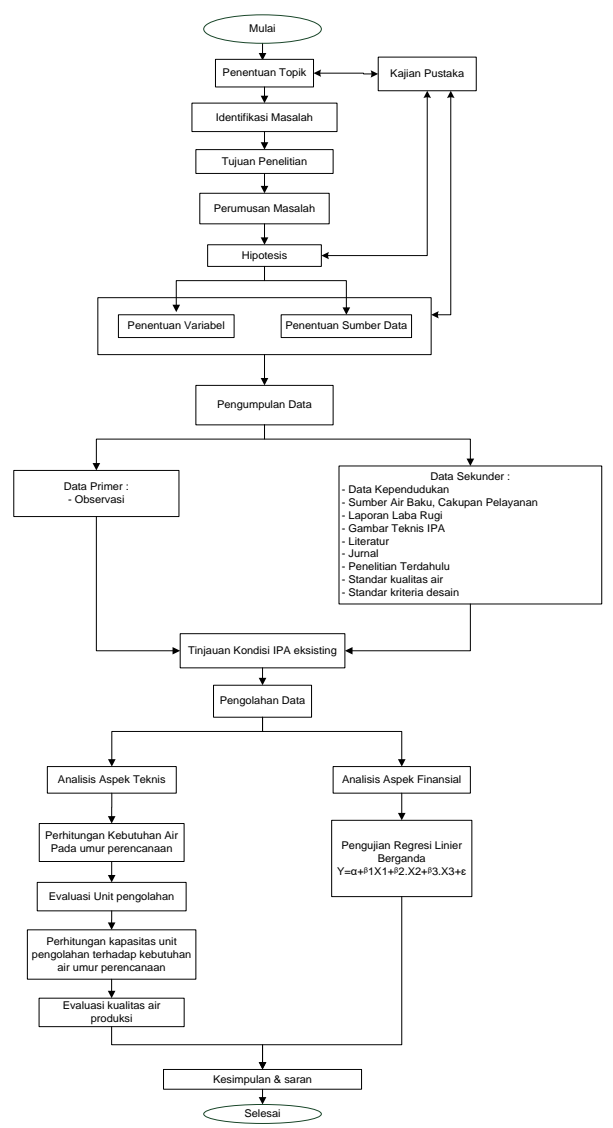

Gambar 3.1 Alur Penelitian

\section{TEKNIK PENGUMPULAN DATA}

Dalam suatu penelitian, teknik pengumpulan data merupakan suatu langkah inti. Dalam pengumpulan data dituntut pengetahuan agar data yang terkumpul benar - benar data yang dibutuhkan. Dalam penelitian ini, teknik pengumpulan data yang digunakan adalah:

a. Observasi

Observasi dilakukan ke instalasi pengolahan air pejompongan I selama 1 hari.

\section{b. Studi Pustaka}

Sebelum melakukan observasi atau kunjungan instalasi, dilakukan terlebih dahulu studi pustaka dalam pengolahan air bersih.

\section{VARIABEL PENELITIAN}

Variabel-variabel yang diperlukan dalam penelitian ini dibagi dalam 2 aspek, yaitu aspek teknis dan aspek finansial.

a. Aspek teknis

Variabel penelitian yang diperlukan adalah :

1. Jumlah penduduk yang berada di wilayah UPP (Unit Pelayanan Palyja) Pusat

2. Kapasitas air produksi

3. Dimensi unit instalasi pengolahan

4. Parameter-parameter kualitas air

b. Aspek finansial

1. Variabel bebas pertama (variabel $\mathrm{X}_{1}$ ) yaitu variabel biaya sumber air.

2. Variabel bebas kedua (variabel $\mathrm{X}_{2}$ ) yaitu variabel yang biaya pengolahan air bersih .

3. Variabel bebas ketiga (variabel $\mathrm{X}_{3}$ ) yaitu variabel penjualan air bersih.

4. Variabel terikat (variabel Y) yaitu variabel laba kotor

\section{METODE ANALISIS DATA}

Metode analisis data yang dilakukan pada penelitian dibagi kedalam aspek teknis dan aspek finansial.

\subsubsection{Metode Statistik Untuk Proyeksi Penduduk}

a. Metode Aritmatika 
Metode ini biasanya disebut juga dengan rata-rata hilang. Rumus metode ini adalah:

$\mathrm{Pn}=\mathrm{P}_{0}+\mathrm{Ka}\left(\mathrm{T}_{\mathrm{n}}-\mathrm{T}_{0}\right)$

$$
K a=\frac{P_{2}-P_{1}}{T_{2}-T_{1}}
$$

Dimana :

Dimana :

$\mathrm{P}_{\mathrm{n}} \quad=$ jumlah penduduk tahun ke-n

$\mathrm{P}_{0} \quad=$ jumlah penduduk awal

$\mathrm{Ka}=$ rasiopertambahan penduduk tiap tahun

$\mathrm{T}_{\mathrm{n}} \quad=$ tahun yang diproyeksi

$\mathrm{T}_{0} \quad=$ tahun awal

\section{b. Metode Geometrik}

Untuk keperluan proyeksi penduduk,metode ini digunakan bila data jumlah penduduk menunjukkan peningkatan yang pesat dari waktu ke waktu. Rumus metode geometrik :

$$
P_{n}=P_{0}(1+r)^{n}
$$

$\mathrm{P}_{\mathrm{n}} \quad=$ jumlah penduduk tahun yang diproyeksi

$\mathrm{P}_{0} \quad=$ jumlah penduduk tahun awal

$\mathrm{r} \quad=$ rata-rata angka pertumbuhan penduduk tiap tahun

n $\quad=$ jangka waktu

c. Metode Regresi Linear

Metode regresi linear dilakukan dengan menggunakan persamaan :

$$
y=a+b x
$$

$$
\begin{aligned}
& a=\frac{\sum y \sum x^{2}-\sum x \sum(x y)}{N \sum x^{2}-\left(\sum x\right)^{2}} \\
& b=\frac{N \sum(x y)-\sum x \sum y}{N \sum x^{2}-\left(\sum x\right)^{2}}
\end{aligned}
$$

Dimana :

y $\quad$ = jumlah penduduk pada tahun perencanaan

$\mathrm{a}, \mathrm{b}=$ konstanta

$\mathrm{x} \quad \dot{=}$ tambahan tahun terhitung dari tahun awal

\subsubsection{Dasar Pemilihan Metode Proyeksi} Penduduk

Korelasi, $r$, dapat dihitung dengan menggunakan rumus :

Kriteria korelasi adalah sebagai berikut :

$$
=\frac{\sum\left(\mathrm{P}_{\mathrm{n}}-\mathrm{P}_{\mathrm{r}}\right)^{2}-\sum\left(\mathrm{P}_{\mathrm{n}}-\mathrm{P}\right)^{2}}{\sum\left(\mathrm{P}_{\mathrm{n}}-\mathrm{P}_{\mathrm{r}}\right)^{2}}
$$


1. $\mathrm{r}<0$, korelasi kuat, tetapi bernilai negatif dan hubungan diantara keduanya dan berbanding terbalik

2. $r=0$, kedua data tidak memiliki hubungan

3. $\mathrm{r}>1$, terdapat hubungan positif dan diperoleh korelasi yang kuat, diantara kedua variabel memiliki hubungan yang berbanding lurus.

Metode proyeksi yang dipilih adalah metode dengan koefisien korelasi paling besar.

\subsubsection{Metode Statistik Untuk Aspek Finansial}

. Dalam metode ini, penulis menggunakan metode regresi linear berganda untuk menganalisis pengaruh biaya produksi air bersih, penjualan air bersih terhadap laba kotor, dengan model regresi dan bantuan program SPSS ver 16 sebagai berikut :

$\mathrm{Y}=\mathrm{f}\left(\mathrm{X}_{1}, \mathrm{X}_{2}, \mathrm{X}_{3}\right)$

Sedangkan persamaan regresinya sebagi berikut :

$$
\begin{array}{ll}
\left.Y=\alpha+\frac{1}{3} .{ }^{\beta}\right)^{\beta} \cdot X_{1}+\beta_{2} \cdot X_{2}+\beta_{3} \cdot X_{3}+\varepsilon & \\
\text { Dimana: } & =\text { variabel terkait } \\
Y & =\text { konstanta } \\
\alpha, \beta & =\text { koefisien regresi } \\
\beta_{1,}, \beta_{2}, \beta_{3} & =\text { variabel regresi } \\
X_{1}, X_{2}, X_{3} & =\text { standar eror }
\end{array}
$$

Untuk mengetahui pengaruh dan hubungan antara variable bebas dan variable terikat dilakukan pengujian hipotesis parsial (uji t statistik) dan hipotesis serentak (uji f statistik).

$t_{\text {hitung }}($ uji $t)=\quad B: S E$ (data dilihat pada tabel print out coefficient)

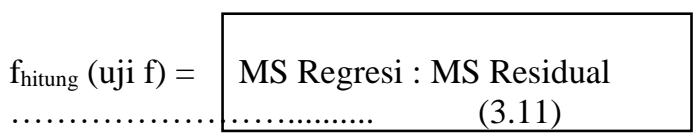

(data dilihat pada tabel print out ANOVA)

BAB 4

\begin{tabular}{|c|c|c|c|}
\hline Tahun & Jumlah Penduduk & Tahun & Jumlah Penduduk \\
\hline 1990 & 1.126 .343 & 2007 & 828.179 \\
\hline 2000 & 1.316 .731 & 2008 & 1.127 .179 \\
\hline 2003 & 889.483 & 2009 & 1.121 .022 \\
\hline 2004 & 886.493 & 2010 & 1.254 .488 \\
\hline 2005 & 861.795 & 2011 & 1.368 .397 \\
\hline 2006 & 883.550 & & \\
\hline
\end{tabular}

\section{HASIL DAN PEMBAHASAN}

\subsection{DATA STATISTIK PENDUDUK}

\begin{tabular}{|l|l|}
\hline Kabupateu & Kecrmatan \\
\hline Jakarta Utara & Penjaringan. Pademangan \\
\hline Jakarta Pusat. & Savah Besar, Gambir. Tanah Abang \\
\hline Jakarta Barat & Tambora, Grogol Petamburan \\
\hline Jakarta Selatan & Satia Budi \\
\hline
\end{tabular}

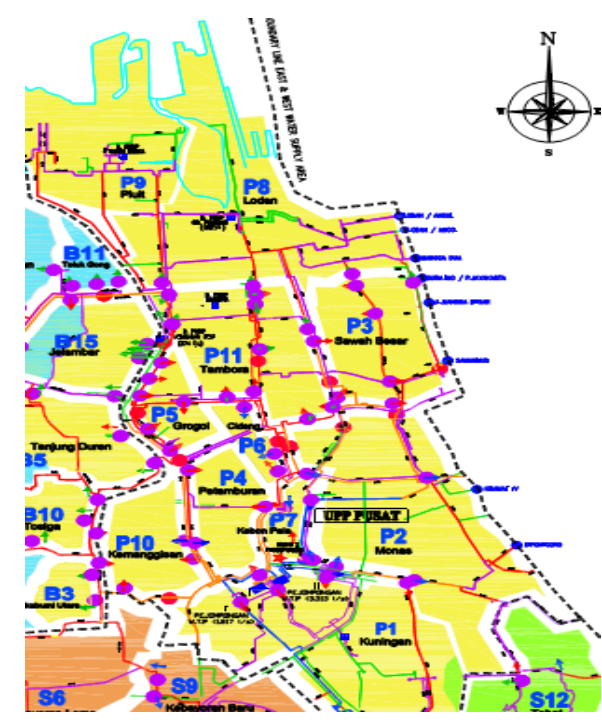

Gambar 4.1 Wilayah UPP Pusat

\subsection{PROYEKSI PENDUDUK}




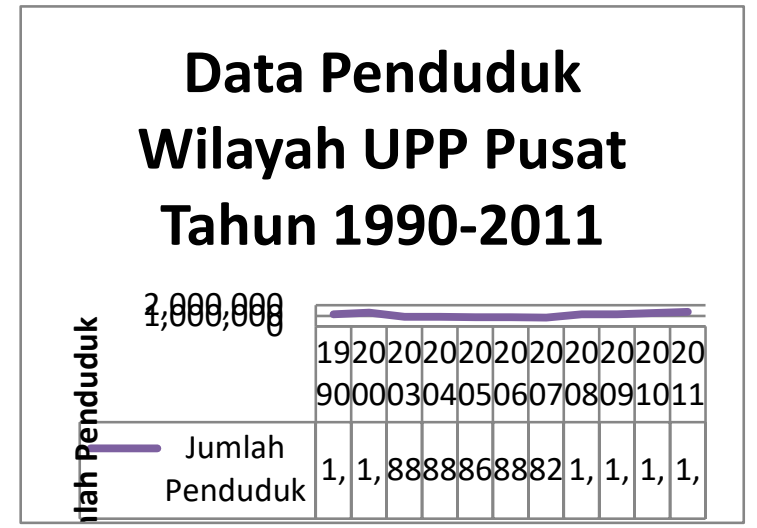

Gambar 4.2 Grafik Data Penduduk Wil UPP Pusat Thn $1990 / 2011$

\subsubsection{Metode Aritmatika} aritmatika

Rumus yang dipergunakan dalam metode

\subsubsection{Metode Geometrik} geometrik

Rumus yang dipergunakan dalam metode

\subsubsection{Metode Least Square} adalah :

Rumus yang digunakan dalam metode ini

$$
\begin{aligned}
& y=a+b x \\
& a=\frac{\sum y \sum x^{2}-\sum x \sum(x y)}{N \sum x^{2}-\left(\sum x\right)^{2}} \\
& b=\frac{N \sum(x y)-\sum x \sum y}{N \sum x^{2}-\left(\sum x\right)^{2}}
\end{aligned}
$$

Sumber : Hasil Perhitungan

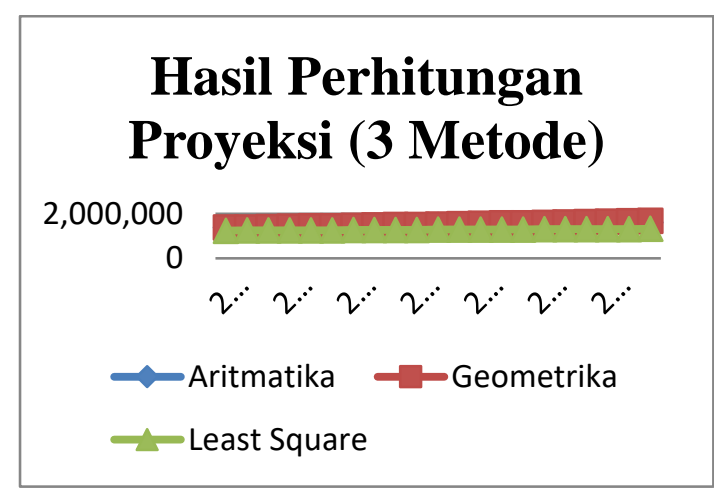

Grafik 2. Hasil Perhitungan Proyeksi Dengan 3 Metode

\subsection{KEBUTUHAN AIR BERSIH}

Pada umumnya kebutuhan air untuk berbagai macam tujuan dapat dibagi menjadi :

1. Kebutuhan Domestik

2. Kebutuhan Non Domestik

\subsubsection{Prediksi Jumlah Kebutuhan Air Domestik}

\subsubsection{Jumlah Kebutuhan Air Bersih SR}

Jumlah jiwa yang dilayani (SR) = Jumlah penduduk $\mathrm{x}$ tingkat pelayanan

Tabel 4.4 Prediksi Jumlah Kebutuhan Air

\begin{tabular}{|c|c|c|c|c|}
\hline \multirow{2}{*}{ Talues } & \multirow{2}{*}{$\begin{array}{l}\text { Jumlah } \\
\text { Pentodale } \\
\text { Dilayasi } \\
\text { (SR) } \\
\text { (orang) }\end{array}$} & \multirow{2}{*}{$\begin{array}{c}\text { Juemlah } \\
\text { Pemalasian } \\
\text { (trir org hasi) }\end{array}$} & \multicolumn{2}{|c|}{$\begin{array}{l}\text { Joemlah Kebotahan Air } \\
\text { SR }\end{array}$} \\
\hline & & & $\mathrm{m}^{2}$ /hasi & In denter \\
\hline (1) & (2) & (3) & $\begin{array}{l}\text { (4) }=(2 \mathrm{x} \\
\text { 3) } / 1000\end{array}$ & $\begin{array}{c}(5)=(4) / \\
s 6,4\end{array}$ \\
\hline 2012 & 1.103 .939 & 150 & 165.591 & 1.917 \\
\hline 2013 & 1.113 .160 & 150 & 166974 & 1.933 \\
\hline 2014 & 1.122 .381 & 150 & 168.357 & 1949 \\
\hline 2015 & 1.131 .602 & 150 & 169.740 & 1965 \\
\hline 2016 & 1.140 .523 & 150 & 171.123 & 1.981 \\
\hline 2017 & 1.150 .044 & 150 & 172507 & 1.997 \\
\hline 2018 & 1.159 .265 & 150 & 173.890 & 2013 \\
\hline 2019 & 1.168 .456 & 150 & 175.273 & 2029 \\
\hline 2020 & 1.177 .708 & 150 & 176.656 & 2045 \\
\hline 2021 & 1.186 .929 & 150 & 178.039 & 2061 \\
\hline 2022 & 1.196 .150 & 150 & 179.422 & 2077 \\
\hline 2023 & 1.205 .371 & 150 & 190.506 & 2093 \\
\hline 2024 & 1.214 .592 & 150 & 182.199 & 2.109 \\
\hline 2025 & 1.223 .813 & 150 & 183.572 & 2.125 \\
\hline 2026 & 1.233 .034 & 150 & 194.955 & 2.141 \\
\hline 2027 & 1.242 .255 & 150 & 196.338 & 2.157 \\
\hline 2028 & 1.251 .476 & 150 & 187.721 & 2.173 \\
\hline 2029 & 1.260 .697 & 150 & 159.105 & 2.199 \\
\hline 2030 & 1.269 .919 & 150 & 190.488 & 2205 \\
\hline 2031 & 1.279 .140 & 150 & 191.871 & 22221 \\
\hline 2032 & 1.258 .351 & 150 & 193.254 & 2237 \\
\hline
\end{tabular}
Sambungan Rumah (SR)

Sampai Dengan Tahun 2032

Sumber : Hasil perhitungan

Keterangan : 86,4 $=(24$ jam $\times 60$ menit $\times 60$ detik) / 1.000 liter

4.3.1.2 Jumlah Kebutuhan Air Bersih HU/ KU 


\begin{tabular}{|c|c|c|c|c|}
\hline \multirow{2}{*}{ Tahroe } & \multirow{2}{*}{$\begin{array}{l}\text { Juemish Unit } \\
\text { (HU) } \\
\text { (orang) }\end{array}$} & \multirow{2}{*}{$\begin{array}{c}\text { Juemiah } \\
\text { Pemalasian } \\
\text { (trorg org hasi) }\end{array}$} & \multicolumn{2}{|c|}{$\begin{array}{c}\text { Jumlah Kebutuban Air } \\
\text { HU KU }\end{array}$} \\
\hline & & & $\mathrm{m}^{2} / \mathrm{hari}$ & Ir detze \\
\hline (1) & (2) & (3) & $\begin{array}{l}\text { (4) }=(2 x \\
\text { 3) } / 1000\end{array}$ & $(5)=(4)$ \\
\hline 2012 & 275.985 & 40 & 11.039 & 128 \\
\hline 2013 & 278.290 & 40 & 11.132 & 129 \\
\hline 2014 & 290.595 & 40 & 11.224 & 130 \\
\hline 2015 & 252901 & 40 & 11.316 & 131 \\
\hline 2016 & 235.206 & 40 & 11.408 & 132 \\
\hline 2017 & 287.511 & 40 & 11.500 & 133 \\
\hline 2018 & 259.816 & 40 & 11.593 & 134 \\
\hline 2019 & 2921122 & 40 & 11.685 & 135 \\
\hline 2020 & 294.427 & 40 & 11.777 & 136 \\
\hline 2021 & 296.732 & 40 & 11.569 & 137 \\
\hline 20022 & 299.037 & 40 & 11.951 & 138 \\
\hline 20023 & 301.343 & 40 & 12054 & 140 \\
\hline 20024 & 303.648 & 40 & 12.146 & 141 \\
\hline 20025 & 305.953 & 40 & 12238 & 142 \\
\hline 2026 & 308.259 & 40 & 12330 & 143 \\
\hline 20027 & 310.564 & 40 & 12.423 & 144 \\
\hline 20028 & 312869 & 40 & 12515 & 145 \\
\hline 2029 & 315.174 & 40 & 12.607 & 146 \\
\hline 2030 & 317.450 & 40 & 12.699 & 147 \\
\hline 2031 & 319.735 & 40 & 12.791 & 148 \\
\hline 2032 & 322090 & 40 & 12854 & 149 \\
\hline
\end{tabular}

Sumber : Hasil perhitungan

Keterangan : $86,4=(24$ jam x 60 menit $x 60$ detik) / 1.000 liter

Sehingga, dapat diprediksikan total kebutuhan air sektor domestik untuk penduduk di wilayah UPP Pusat hingga pada tahun 2032 adalah sebagai berikut :

Tabel 4.6 Total Kebutuhan Air Untuk Sektor Domestik

\begin{tabular}{|c|c|c|c|c|}
\hline \multirow{3}{*}{ Tahur } & \multicolumn{2}{|c|}{ 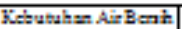 } & \multirow{2}{*}{\multicolumn{2}{|c|}{ 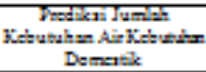 }} \\
\hline & \multirow{2}{*}{$\begin{array}{c}\mathrm{SR} \\
\text { mithen }\end{array}$} & \multirow{2}{*}{ hu } & & \\
\hline & & & $m^{2} h=$ & lodetik \\
\hline (1) & (2) & (3) & $(4)-(2)-(3)$ & $\begin{array}{r}(5)- \\
(4) 66,4\end{array}$ \\
\hline $20: 2$ & 165.59 & 11.039 & 176.630 & 2.044 \\
\hline 2013 & 166.974 & 11.132 & 178.106 & $2.06 !$ \\
\hline 2014 & 168.357 & 11.224 & 179.581 & 2.078 \\
\hline 2015 & 169.740 & 11.316 & 131.056 & 2.096 \\
\hline 2016 & 171.128 & 11.408 & 182.532 & 2.113 \\
\hline $20: 7$ & 172.507 & 11.500 & 184.007 & 2.130 \\
\hline 2013 & 173.890 & 11.593 & 185.432 & 2.147 \\
\hline 2010 & 175.273 & 11.685 & 186.058 & 2.164 \\
\hline 2020 & 176.656 & 11.777 & 193.493 & 2.181 \\
\hline 2021 & 178.030 & 11.869 & 190.900 & 2.193 \\
\hline 2022 & 179.422 & 11.961 & 191.384 & 2.215 \\
\hline 2023 & 180.806 & 12.054 & 102.850 & 2.232 \\
\hline 2024 & 182.120 & 12.146 & 104.395 & 2.240 \\
\hline 2025 & 183.572 & 12.298 & 105.810 & 2.266 \\
\hline 2026 & 184.955 & 12.390 & 187.285 & 2.233 \\
\hline 2027 & 186.338 & 12.423 & 193.761 & 2.300 \\
\hline 2023 & 187.721 & 12.515 & 200.296 & 2.318 \\
\hline 2029 & 199.105 & 12.607 & $201.7: 2$ & 2.395 \\
\hline 2030 & 190.438 & 12.690 & 203.187 & 2.352 \\
\hline $203:$ & 191.872 & 12.791 & 204.662 & 2.360 \\
\hline 2032 & 109.254 & 12.834 & 206.198 & 2.386 \\
\hline
\end{tabular}

Sumber : Hasil perhitungan
Keterangan : $86,4=(24$ jam $\times 60$ menit $\times 60$ detik) / 1.000 liter

\subsubsection{Prediksi Jumlah Kebutuhan Air Non Domestik}

Perhitungan kebutuhan air non domestik untuk wilayah kategori Kota Metropolitan ini diprediksikan dengan kriteria berdasarkan standar dari Dirjen Cipta Karya Dinas Pekerjaan Umum Tahun 1996

\subsubsection{Jumlah Kebutuhan Air Bersih Untuk Sarana Pendidikan}

Jumlah kebutuhan air (pendidikan) $=$ jumlah jiwa yang dilayani $\mathrm{x}$

jumlah pemakaian

(pada tahun 2012) $=316.536$ jiwa $\times 10$ lt/org/hari :

1000

$=3.165 \mathrm{~m}^{3} /$ hari $=36,64 \mathrm{lt} / \mathrm{detik}$

\subsubsection{Jumlah Kebutuhan Air Bersih Untuk Sarana Kesehatan}

Jumlah kebutuhan air (kesehatan) = jumlah unit yang dilayani $\mathrm{x}$ jumlah pemakaian (pada tahun 2012) $=1.134$ unit x 2000 lt/unit/hari :

1000

$=2.268 \mathrm{~m} 3 / \mathrm{hari}=26,25 \mathrm{lt} / \mathrm{detik}$.

\subsubsection{Jumlah Kebutuhan Air Bersih Untuk Sarana Peribadatan}

Jumlah kebutuhan air (peribadatan) $=$ jumlah unit yang dilayani $\mathrm{x}$ jumlah pemakaian

(pada tahun 2012)

$=1.151$ unit x $3000 \mathrm{lt} /$ unit/hari : 1000

$=3.453 \mathrm{~m}^{3} /$ hari $=39,97 \mathrm{lt} / \mathrm{detik}$

\subsubsection{Jumlah Kebutuhan Air Bersih Untuk Sarana Penginapan}

Jumlah kebutuhan air (penginapan) = jumlah bed yang dilayani $\mathrm{x}$ jumlah pemakaian 
(pada tahun 2012)

$=10.551$ unit $\times 150 \mathrm{lt} /$ bed $/$ hari : 1000

$=1.583 \mathrm{~m}^{3} / \mathrm{hari}=18,32 \mathrm{lt} / \mathrm{detik}$

\subsubsection{Jumlah Kebutuhan Air Bersih Untuk} Pasar

Jumlah kebutuhan air (pasar) = areal pasar yang dilayani $\mathrm{x}$ jumlah pemakaian

(pada tahun 2012)

$=30$ ha $\times 12.000$ lt/ha/hari : 1000

$=360 \mathrm{~m}^{3} /$ hari $=4,17 \mathrm{lt} /$ detik

\subsubsection{Jumlah Kebutuhan Air Bersih Untuk Sarana Umum}

Jumlah kebutuhan air (sarana umum)

$=$ areal pasar yang dilayani $\mathrm{x}$ jumlah pemakaian

(pada tahun 2012)

$=1.062$ ha $x 12.000 \mathrm{lt} / \mathrm{ha} /$ hari : 1000

$=12.744 \mathrm{~m}^{3} / \mathrm{hari}=147,50 \mathrm{lt} / \mathrm{detik}$

\subsubsection{Jumlah Kebutuhan Air Bersih Untuk Perkantoran}

Jumlah kebutuhan air (pegawai) = jumlah pegawai dilayani $\mathrm{x}$ jumlah pemakaian

(pada tahun 2012)

$=9.877 \times 10$ lt/org/hari : 1000

$=98,77 \mathrm{~m}^{3} /$ hari $=1,14 \mathrm{lt} /$ detik

\subsection{EVALUASI UNIT PENGOLAHAN \\ 4.4.1 Unit Koagulasi}

Profil aliran kecepatan distribusi dalam bak koagulasi dapat dilihat pada grafik dibawah ini.

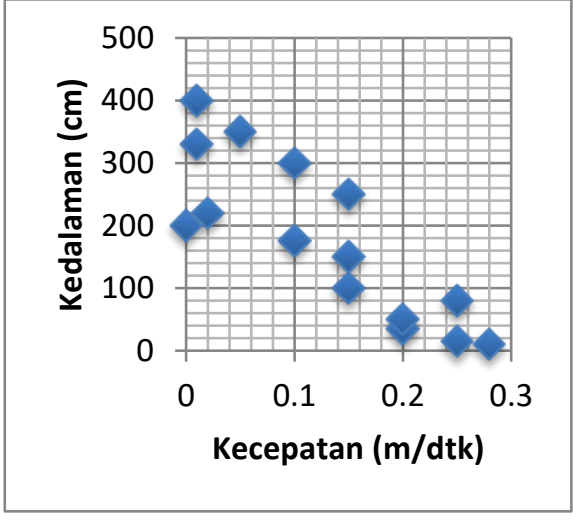

(a)Bak Kesatu

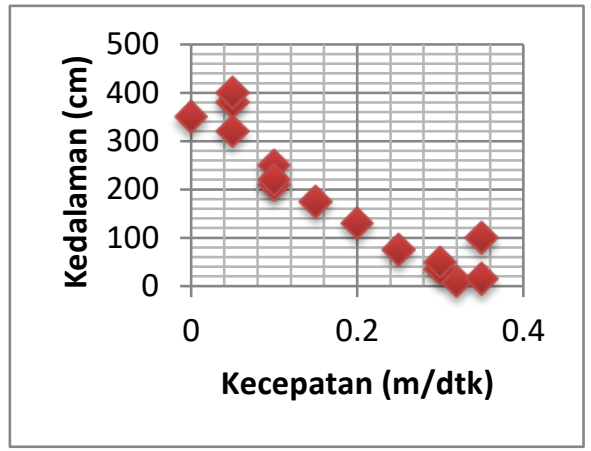

(a)Bak Kedua

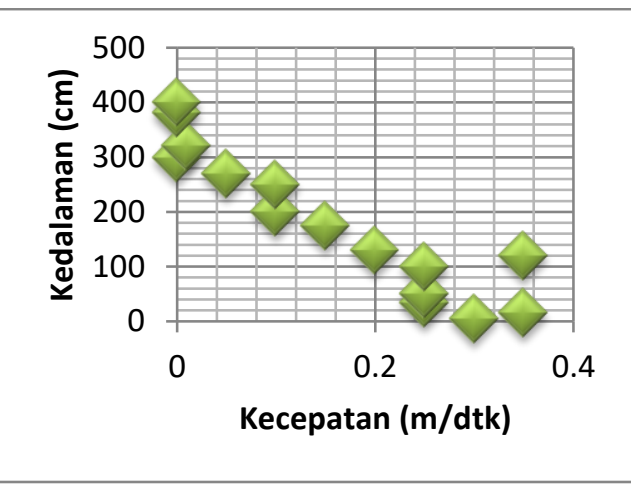

(a) Bak Ketiga

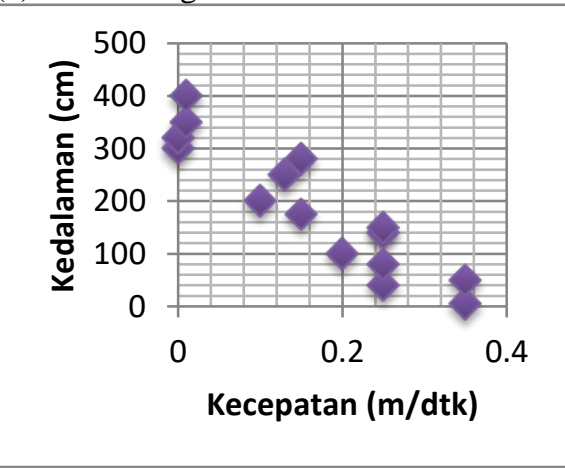

(a) Bak Keempat 


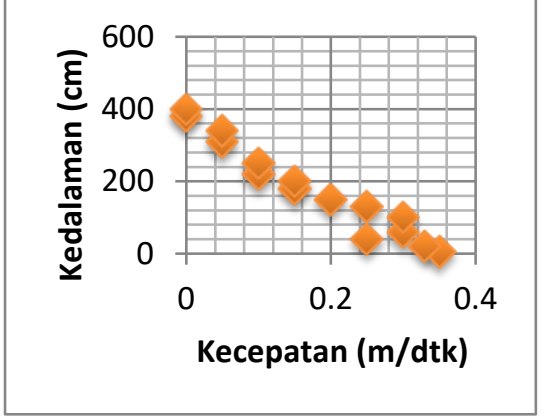

(a) Bak Kelima

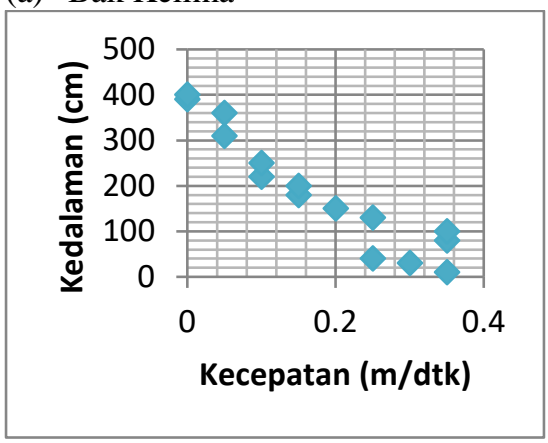

(a) Bak Keenam

Gambar 4.3 Profil Aliran Kecepatan Bak Koagulasi

$$
\begin{aligned}
& G=\sqrt{\frac{4 \mathrm{~m} \times 9,81 \mathrm{~m} / \text { detik }^{2}}{8,394 \times 10^{-7} \mathrm{~m} / \text { detik }^{2} \times 37,01 \text { detik }}}= \\
& 355,31 \text { detik }^{-1}
\end{aligned}
$$

a. $\quad \mathrm{NRe}$

$N \operatorname{Re}=v \cdot R / v$

$N \operatorname{Re}=0,486 \times 0,356 / 8,394 \times 10^{-7} \mathrm{~m}$ detik $^{2}$ $=20.616,55$

Dari perhitungan diatas, diperoleh $\mathrm{Q}, \mathrm{td}, \mathrm{G}$ dan NRe untuk masing-masing bak seperti tabel dibawah ini :

Tabel 4.9 Hasil Perhitungan Bak Koagulasi

\begin{tabular}{|l|l|l|l|}
\hline \multicolumn{1}{|c|}{ Bak } & Td (detik) & \multicolumn{1}{|c|}{$\begin{array}{c}\text { N } \\
\text { (detik }^{-1} \text { ) }\end{array}$} & NRe \\
\hline 1 & 37.01 & 355.31 & $20,616.55$ \\
\hline 2 & 30.64 & 390.46 & $24,897.54$ \\
\hline 3 & 35.75 & 361.49 & $21,339.94$ \\
\hline 4 & 31.49 & 385.20 & $24,230.66$ \\
\hline 5 & 34.88 & 365.96 & $21,871.18$ \\
\hline 6 & 27.54 & 411.90 & $27,706.31$ \\
\hline
\end{tabular}

\subsubsection{Unit Flokulasi}

\section{Perhitungan}

1. Daya atau power

$$
\begin{aligned}
P & =N_{P} \cdot \mu \cdot n^{2} \cdot d^{3} \\
\mathrm{P} & =6,2 \times 0,798 \times 10^{3} \times(1500 / 60) \times 6^{3} \\
& =667,926 \mathrm{~N}-\mathrm{m} / \mathrm{dt}
\end{aligned}
$$

2. Bilangan Reynolds

$$
N_{\mathrm{Re}}=d^{2} . n \cdot \rho / \mu
$$

$\mathrm{N}_{\mathrm{Re}}=6^{2} \times(1500 / 60) \times 996 /(0,798 \times$ $\left.10^{3}\right)$

$$
=1,123 \times 10^{9}
$$

3. Gradien kecepatan

$$
\begin{aligned}
& G=\sqrt{\frac{P}{\mu \bullet V}}=\sqrt{\frac{667,926}{0,798 \times 10^{3} \bullet 466}} \\
& =42,38
\end{aligned}
$$

4. Waktu tinggal per bak (bak kesatu)

$$
t_{d}=\frac{V}{Q_{1}}=\frac{466}{0,486}=958,05 \text { detik }=
$$

15,97 menit

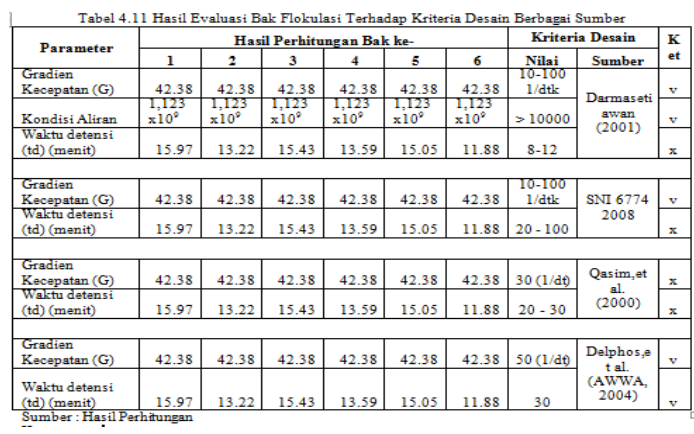

Keterangan :

$\mathrm{x}=$ tidak sesuai dengan kriteria desain

$\mathrm{v}=$ sesuai dengan kriteria desain

\subsubsection{Unit Sedimentasi}


Tabel 4.13 Hasil Evaluasi Bak Sedimentasi Terhadap Kriteria Desain Berbagą Sumber

\begin{tabular}{|c|c|c|c|c|}
\hline \multirow{2}{*}{ Parameter } & \multirow{2}{*}{ Satuan } & \multirow{2}{*}{$\begin{array}{c}\text { Hasil } \\
\text { Perhitungan }\end{array}$} & $\begin{array}{c}\text { Kriteria } \\
\text { Dessin }\end{array}$ & Ket \\
\hline & & & $\begin{array}{c}\text { SN1 } 6774 \\
2008\end{array}$ & \\
\hline Beban permuksan & $\mathrm{m}^{y} / \mathrm{m}^{2} \mathrm{jam}$ & 45 & $0.5 \cdot 1.5$ & $\mathrm{x}$ \\
\hline Kedalaman & $\mathrm{m}$ & 3 & $0.5-1$ & $\mathrm{x}$ \\
\hline Waktu tinggal & $\mathrm{jam}$ & 0.06 & $2-2.5$ & $\mathrm{x}$ \\
\hline Beban Pelimpah & $\mathrm{m}^{\mathrm{y}} / \mathrm{m} \mathrm{jam}$ & 64.28 & $7.2-10$ & $\mathrm{x}$ \\
\hline Bilangan Raynolds & & 319.27 & $<2000$ & $\mathrm{v}$ \\
\hline Bilangan Froude & & $1 \times 10^{-4}$ & $>10^{-4}$ & $\mathrm{v}$ \\
\hline Kemiringan dasar bak (tanpa scraper) & & $60^{\circ}$ & $45^{\circ}-60^{\circ}$ & $\mathrm{v}$ \\
\hline Kemiringan tubs/plate & & $60^{\circ}$ & $30^{\circ}-60^{\circ}$ & $\mathrm{v}$ \\
\hline
\end{tabular}

\begin{tabular}{|c|c|c|c|c|}
\hline \multirow[t]{2}{*}{ Parameter } & \multirow[t]{2}{*}{ Satuan } & \multirow{2}{*}{$\begin{array}{c}\text { Hasil } \\
\text { Perhitungan }\end{array}$} & $\begin{array}{l}\text { Kriteria } \\
\text { Dessain }\end{array}$ & \multirow[t]{2}{*}{ Ket } \\
\hline & & & Reynolds & \\
\hline Rasio panjanglebar & & 2.5 & $3: 1-5: 1$ & $x$ \\
\hline Surface loadingrate & $\mathrm{m}^{3} / \mathrm{m}^{2} / \mathrm{hari}$ & 1247.11 & $60-150$ & $\mathrm{x}$ \\
\hline Kecepatan pada settler & $\operatorname{mimin}$ & 0.87 & $0.05-0.13$ & $\mathrm{x}$ \\
\hline Weir losding rate & $\mathrm{m}^{y} / \mathrm{m} / \mathrm{hari}$ & 1542.85 & $90-360$ & $x$ \\
\hline Weir losdingrate (saat pengurassan) & $\mathrm{m}^{3} / \mathrm{m}$ hari & 561.6 & $90-360$ & $\mathrm{x}$ \\
\hline Bilangan Reynolds & & 319.27 & $<2000$ & $\mathrm{v}$ \\
\hline Bilangan Froude & & $1 \times 10^{4}$ & $>10^{\circ}$ & $\mathrm{v}$ \\
\hline Waktud detensi bak & menit & 4 & $<120$ menit & $\mathrm{v}$ \\
\hline
\end{tabular}

Keterangan :

$\mathrm{x}=$ tidak sesuai dengan desain

$\mathrm{v}=$ sesuai dengan desain 


\subsubsection{Filtrasi}

\section{Data eksisting}

Tabel 4.14 Hasil Evaluasi Filtrasi Terhadap Kriteria Desain Berbagagi Sumber

\begin{tabular}{|c|c|c|c|c|}
\hline \multirow{2}{*}{ Parameter } & \multirow{2}{*}{ Satuan } & \multirow{2}{*}{ Hasil Perhitungan } & \begin{tabular}{|l} 
Kriteria Desain \\
\end{tabular} & \multirow[t]{2}{*}{ Keterangan } \\
\hline & & & Reynolds (1982) & \\
\hline Jumlah Bak & buah & 17 & $\min 2$ & $\mathrm{v}$ \\
\hline Kecapstan Aliran Pipa Inlet & midth & 0,49 & $0,6-1,8$ & $\mathrm{x}$ \\
\hline Kecapatan Aliran Pipa Outlet & midtk & 0,49 & $0,6 \cdot 1,8$ & $x$ \\
\hline Lebar bak & $\mathrm{m}$ & 4 & 3.6 & $\mathrm{v}$ \\
\hline Perbandingan parjang \& lebar bak & & $2: 1 \cdot 4: 1$ & 2,5 & $\mathrm{v}$ \\
\hline Kedalaman bak & $\mathrm{m}$ & 5 & $5,5 \cdot 7,5$ & $\mathrm{x}$ \\
\hline Kedalaman medis filter & $\mathrm{cm}$ & $70 \mathrm{~cm}$ & 90 & $x$ \\
\hline Kedalaman media penyangega & $\mathrm{cm}$ & 30 & 10 & $x$ \\
\hline Luas permukaan filter & $\mathrm{m}^{2}$ & 41,4 & $25-80$ & $\mathrm{v}$ \\
\hline Kecepatan filtrasi (nomal) & $\mathrm{m}^{3} /$ harri-m & 86,82 & $100-475$ & $x$ \\
\hline Kecepatan sastbackwash & $\mathrm{m}^{3} / \mathrm{hari}-\mathrm{m}^{2}$ & 10,37 & $100-475$ & \\
\hline
\end{tabular}

\begin{tabular}{|c|c|c|c|c|}
\hline \multirow{2}{*}{ Parameter } & \multirow{2}{*}{ Satuan } & \multirow{2}{*}{ Hasil Perhitungan } & Kriteria Desain & \multirow{2}{*}{ Keterangan } \\
\hline & & & SNI 67742008 & \\
\hline Jumlah Bak & buah & 17 & $\mathrm{~N}=12 Q^{0,2}$ & v \\
\hline Sistem Pencucian & & Dengan blower & $\begin{array}{l}\text { tanpa dengan } \\
\text { blower \& atau } \\
\text { sufface wash }\end{array}$ & $\mathrm{v}$ \\
\hline Kedalaman madia filter & $\mathrm{cm}$ & 70 & 30.70 & $\mathrm{v}$ \\
\hline Kedalaman media payyangga & $\mathrm{cm}$ & 30 & 40.50 & $x$ \\
\hline Kecepsatan filtrasi (nomal) & mjam & 86,82 & 36.50 & $x$ \\
\hline Periode antara dua pencucimn & $\mathrm{jm}$ & 24.48 & 18.24 & $\mathrm{v}$ \\
\hline
\end{tabular}

Keterangan : $\quad \mathrm{x}=$ tidak sesuai dengan desain $\quad \mathrm{V}=$ sesuai dengan desain

\subsubsection{Desinfektan}

Desinfektan yang digunakan adalah gas chlor,dan masih berfungsi dengan baik. Sistem chlorinatornya sangat sederhana dengan mengandalkan penguapan yang terjadi di gas chlor. Pada IPA Pejompongan, clorinator yang digunakan menggunakan pompa booster yang kemudian disuntikkan pada bak reservoar.

\subsubsection{Reservoir}

\subsection{ANALISIS KETERSEDIAAN AIR PRODUKSI TERHADAP KEBUTUHAN AIR}

\subsubsection{Proyeksi Ketersediaan Air}

Dalam memproyeksikan kemampuan debit pengolahan atau kapasitas air produksi yang mampu diproduksikan oleh IPA Pejompongan untuk masa yang akan datang maka diperlukan rekapitulasi data yang debit yang dihasilkan pada tahun 2007 - 2011 .

Dari data rekapitulasi diatas, maka dapat diproyeksikan jumlah debit IPA Pejompongan hingga tahun 2032 menggunakan perhitungan dengan rumus regresi linear seperti pada tabel dibawah ini :

\begin{tabular}{|c|c|c|c|c|c|}
\hline \multirow{2}{*}{ Bulan } & \multicolumn{5}{|c|}{ IPA PEJOMPONGAN 1 (lt/dtk) } \\
\hline & 2007 & 2008 & 2009 & 2010 & 2011 \\
\hline $\operatorname{Tan}$ & 2500 & 2500 & 2100 & 2100 & 2100 \\
\hline Feb & 1900 & 1900 & 1800 & 1700 & 1800 \\
\hline Mar & 1900 & 1800 & 1700 & 1700 & 1800 \\
\hline Apr & 1800 & 1800 & 1700 & 1700 & 1700 \\
\hline Mei & 1800 & 1800 & 1700 & 1700 & 1700 \\
\hline Jun & 1800 & 1800 & 1700 & 1700 & 1700 \\
\hline Jul & 1800 & 1800 & 1700 & 1700 & 1700 \\
\hline Agust & 1900 & 1900 & 1800 & 1700 & 1800 \\
\hline Sep & 1900 & 2000 & 1900 & 1700 & 1800 \\
\hline Okt & 2500 & 2500 & 2400 & 2100 & 2400 \\
\hline Nop & 2500 & 2500 & 2400 & 2100 & 2400 \\
\hline Des & 1800 & 1800 & 1700 & 1700 & 1700 \\
\hline Rata-rata & 1900 & 1800 & 1700 & 1700 & 1800 \\
\hline
\end{tabular}

Tabel 4.16 Rekapitulasi Debit Kapasitas Air Produksi Tahun 2007-2011

\begin{tabular}{|c|c|c|c|c|c|}
\hline \multirow{2}{*}{ Bulan } & \multicolumn{5}{|c|}{ IPA PEJOMPONGAN 1 (lt/dtk) } \\
\hline & 2007 & 2008 & 2009 & 2010 & 2011 \\
\hline $\operatorname{Jan}$ & 2500 & 2500 & 2100 & 2100 & 2100 \\
\hline Feb & 1900 & 1900 & 1800 & 1700 & 1800 \\
\hline Mar & 1900 & 1800 & 1700 & 1700 & 1800 \\
\hline Apr & 1800 & 1800 & 1700 & 1700 & 1700 \\
\hline Mei & 1800 & 1800 & 1700 & 1700 & 1700 \\
\hline Jun & 1800 & 1800 & 1700 & 1700 & 1700 \\
\hline Jul & 1800 & 1800 & 1700 & 1700 & 1700 \\
\hline Agust & 1900 & 1900 & 1800 & 1700 & 1800 \\
\hline Sep & 1900 & 2000 & 1900 & 1700 & 1800 \\
\hline Okt & 2500 & 2500 & 2400 & 2100 & 2400 \\
\hline Nop & 2500 & 2500 & 2400 & 2100 & 2400 \\
\hline Des & 1800 & 1800 & 1700 & 1700 & 1700 \\
\hline Rata-rata & 1900 & 1800 & 1700 & 1700 & 1800 \\
\hline
\end{tabular}
Tabel 4.17 Perhitungan Ketersediaan Debit IPA Pejompongan

\begin{tabular}{|c|c|c|c|c|c|c|}
\hline No. & Tahun & 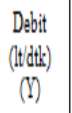 & $\begin{array}{c}\text { Jumlah Data } \\
\text { (X) }\end{array}$ & $Y^{t}$ & $X^{2}$ & $X Y$ \\
\hline 1 & 2007 & 1.900 & 1 & 3610000 & 1 & 1900 \\
\hline 2 & 2008 & 1.800 & 2 & 3240000 & 4 & 3600 \\
\hline 3 & 2009 & 1.700 & 3 & 2890000 & 9 & 5100 \\
\hline 4 & 2010 & 1.700 & 4 & 2890000 & 16 & 6800 \\
\hline 5 & 2011 & 1.800 & 5 & 3240000 & 25 & 9000 \\
\hline & $\Sigma$ & 8.900 & 15 & $15: 870,000$ & 35 & 26.400 \\
\hline
\end{tabular}

$$
b=\frac{\left[\left(n \times \sum X Y\right)-\left(\sum X \times \sum Y\right)\right]}{\left[\left(n \times \sum X^{2}\right)-\left(\sum X\right)^{2}\right]}
$$$$
b=\frac{[(5 \times 26.400)-(15 \times 8.900)]}{\left[(5 \times 55)-(15)^{2}\right]}=-30
$$

$$
a=\frac{\sum Y-b \sum X}{n}=\frac{8.900-(-30.15)}{5}=1.870
$$

$\mathrm{Y}=\mathrm{a}+\mathrm{b}^{*} \mathrm{X}-->$ dimana $\mathrm{x}$ adalah tahun proyeksi 
$\mathrm{Y}=1.870+(-30 * 6)=1.690$

Prediksi debit IPA PJ untuk tahun 2012 sebesar 1.690 lt/dtk. Hasil perhitungan hingga tahun 2032 dapat dilihat pada tabel dibawah ini.

\begin{tabular}{|c|c|c|c|c|c|}
\hline Tahun & $\mathrm{x}$ & $\begin{array}{c}\text { Prediksi } \\
\text { debit } \\
\text { (lt/dtk) }\end{array}$ & Tahun & $x$ & $\begin{array}{c}\text { Prediksi } \\
\text { debit } \\
\text { (lt/dtk) }\end{array}$ \\
\hline 2012 & 6 & 1690 & 2023 & 17 & 1360 \\
\hline 2013 & 7 & 1660 & 2024 & 18 & 1330 \\
\hline 2014 & 8 & 1630 & 2025 & 19 & 1300 \\
\hline 2015 & 9 & 1600 & 2026 & 20 & 1270 \\
\hline 2016 & 10 & 1570 & 2027 & 21 & 1240 \\
\hline 2017 & 11 & 1540 & 2028 & 22 & 1210 \\
\hline 2018 & 12 & 1510 & 2029 & 23 & 1180 \\
\hline 2019 & 13 & 1480 & 2030 & 24 & 1150 \\
\hline 2020 & 14 & 1450 & 2031 & 25 & 1120 \\
\hline 2021 & 15 & 1420 & 2032 & 26 & 1090 \\
\hline 2022 & 16 & 1390 & & & \\
\hline
\end{tabular}

Sumber :Hasil perhitungan

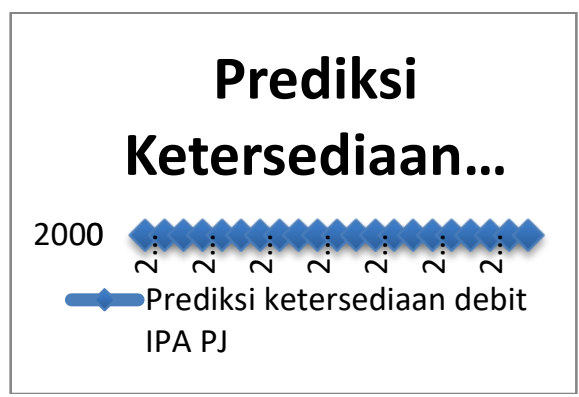

Gambar 4.4 Prediksi Ketersediaan Debit IPA PJ

Tabel 4.19 Hasil Perhitungan Proyeksi Debit Yang Dibutuhkan Terhadap Ketersediaan Air IPA Pejompongan Dan Terhadap Prediksi Kekurangan Debit

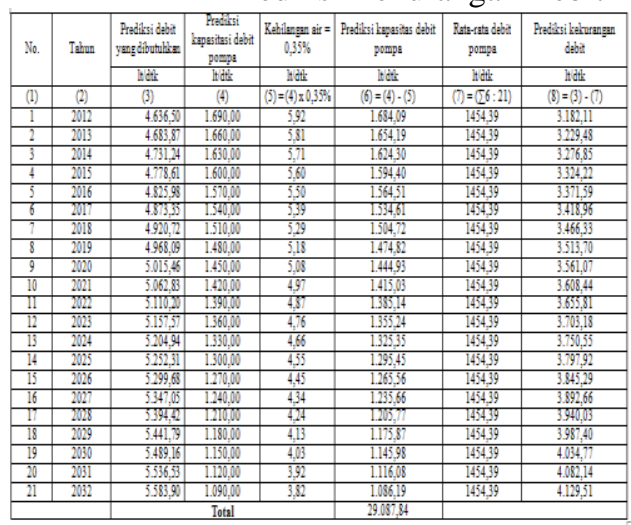

Sumber : Hasil Perhitungan

Proyeksi debit yang dibutuhkan diperoleh dari tabel 4.8 dengan debit air di jam puncak dan nilai kehilangan rata-rata sebesar $0,35 \%$ diperoleh dari nilai rata-rata kehilangan air pada annual report tahunan.

\subsubsection{Hubungan Ketersediaan Air Bersih Terhadap Kebutuhan Air \\ Dari perhitungan diatas, dapat dilihat} hubungan ketersediaan air bersih dengan kebutuhan air bersih untuk penduduk wilayah unit UPP Pusat hingga tahun 2032 dalam grafik dibawah ini.

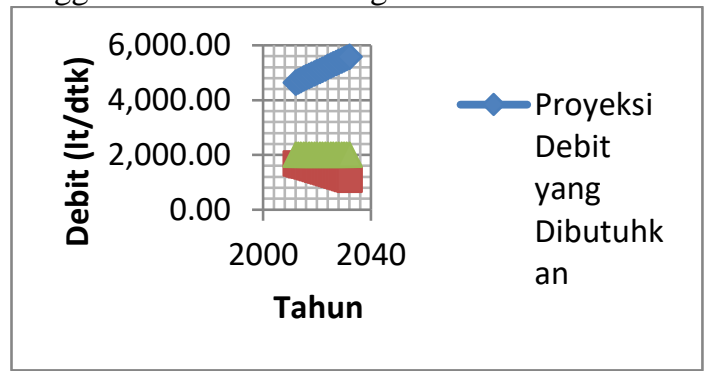

Gambar 4.5 Hubungan Proyeksi Debit Yang Dibutuhkan Terhadap Kapasitas Debit IPA PJ

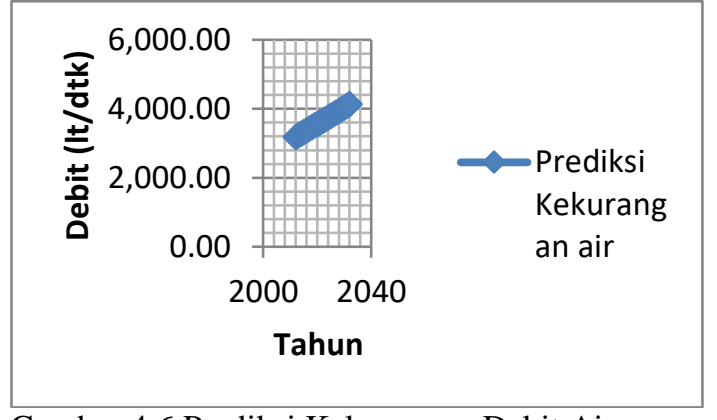

Gambar 4.6 Prediksi Kekurangan Debit Air

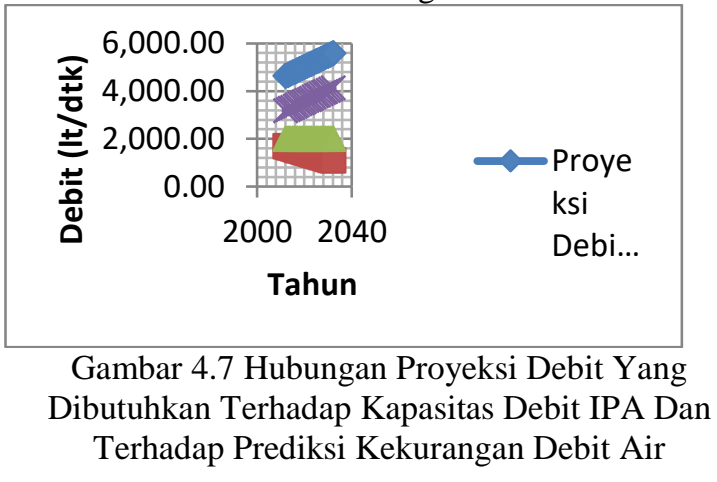

\subsubsection{Upaya Untuk Memenuhi Kekurangan Kebutuhan Air Bersih Wilayah UPP Pusat IPA Pejompongan}

\subsection{EVALUASI KUALITAS AIR}

\subsubsection{Kualitas Air Baku}

Penelitian kualitas air dibagi dalam 3 parameter, yaitu sifat fisik, kimia dan mikrobiologi. Sampel dilakukan secara blind tanpa mengetahui titik lokasi sampel diambil. Berikut ini adalah kualitas air sumber air baku di beberapa titik sumber air baku. 


\begin{tabular}{|c|c|c|c|c|c|c|c|c|}
\hline No. & Parameter & Satuan & 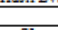 & Titiks & mpling & & Kriteria & Ket \\
\hline & & & 51 & & & 54 & & \\
\hline $\begin{array}{l}1 \\
1 .\end{array}$ & $\begin{array}{l}\text { FiskA } \\
\text { Suhu }\end{array}$ & ${ }^{\circ} \mathrm{C}$ & 27.6 & 27.8 & 27,3 & 27,6 & $\begin{array}{l}\text { Suhu air } \\
\text { nomal }\end{array}$ & $\mathrm{v}$ \\
\hline 2 & Bau & - & & - & Busuk & - & 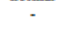 & $x$ \\
\hline & & & Asam & & pahit & & & \\
\hline 4. & Zat Padat Terlanut & $\operatorname{mg} 1$ & 183,33 & 116,67 & 270 & 586,67 & 1000 & $\mathrm{v}$ \\
\hline 5. & $\begin{array}{l}\text { Zat Padat } \\
\text { Tersuspensi }\end{array}$ & $\operatorname{mg} 1$ & & 1.8 & 6 & 2,67 & 50 & $\mathrm{v}$ \\
\hline II & $\underset{\mathrm{Kn}}{\mathrm{KnA}}$ & & & & & & & \\
\hline 2. & DO & $\operatorname{mg} 1$ & 1,96 & 2,35 & 0.98 & 2,00 & $\geq 6$ & v \\
\hline 3. & BOD & $\mathrm{mg} 1$ & 317 & 83.2 & 214 & 29,7 & 2 & $\mathrm{x}$ \\
\hline 4. & COD & mg1 & 952 & 208,25 & $\begin{array}{l}646 \\
688\end{array}$ & $\begin{array}{l}119 \\
4,15\end{array}$ & 05 & $x$ \\
\hline 6. & Nitrit & mg 1 & 0,001 & 0,009 & 0,014 & 0.375 & 0.06 & $\mathrm{x}$ \\
\hline & Nitrat & $\mathrm{mg} 1$ & 0.21 & 0,001 & 0,001 & 0,0042 & 10 & \\
\hline 8. & Fosfat & $\operatorname{mg} 1$ & 0,0005 & 0,0005 & 0,503 & 0,0005 & 0,2 & $\mathrm{v}$ \\
\hline 0 & Besi $(\mathrm{Fe})$ & $\mathrm{mg} 1$ & Ttd & Ttd & Tid & Trd & 0,3 & - \\
\hline 10. & Timbal $(\mathrm{Pb})$ & $\mathrm{mg} 1$ & Trd & Ttd & Trd & Trd & 0,03 & $\cdot$ \\
\hline 11. & Tembaga $(\mathrm{Cu})$ & $\mathrm{mg} 1$ & 0,014 & 0,012 & 0,018 & Itd & 0.02 & $\mathrm{v}$ \\
\hline 12. & $\operatorname{Krom}(C t)$ & mg1 & Tid & Tid & Titd & Trd & 0.05 & \\
\hline 13. & Kadnium (Cd) & $\mathrm{mg} 1$ & Trd & Trd & Ttd & Trd & 0.01 & $\cdot$ \\
\hline 14. & Seng $(\mathrm{Zn})$ & $\mathrm{mg} 1$ & Ttd & 0,002 & 0,129 & Tdd & 0,05 & v \\
\hline 1. & Fecal Coli & M.PN/100 & - & 1500 & 3500 & 120 & 100 & $\mathrm{x}$ \\
\hline 2. & Coliform & MPN/100 & - & 7000 & 10000 & 300 & 1000 & $x$ \\
\hline
\end{tabular}

Kerangan :

$\mathrm{v}=$ masih dibawah batas kadar maksimum yang diperbolehkan

$\mathrm{x}=$ diatas batas kadar maksimum yang diperbolehkan

\subsubsection{Kualitas Air Produksi}

Tabel 4.21 Hasil Evaluasi Kualitas Air Produksi

\begin{tabular}{|c|c|c|c|c|c|}
\hline So & Jemin Parsmeter & Sattuan & Kadar & $\begin{array}{c}\text { Kadar maks } \\
\text { yang } \\
\text { diperboleblkan }\end{array}$ & Ket \\
\hline 1 & $\begin{array}{l}\text { Fax } \\
\text { Bas }\end{array}$ & & & & \\
\hline 2 & Wara & TCU & & 15 & $v$ \\
\hline 3. & $\begin{array}{l}\text { Total Zat padat } \\
\text { tedarst(TDS) }\end{array}$ & & 143 & & \\
\hline 4 & $\begin{array}{l}\text { Tekerobas } \\
\text { Ran }\end{array}$ & NTU & $\begin{array}{c}1 \\
\text { Tistíntan }\end{array}$ & $\frac{5}{\text { Tistak beran }}$ & $v$ \\
\hline 6. & Satm & ${ }^{\circ} \mathrm{C}$ & & Saber vasas \pm 3 & v \\
\hline 1 & Abeminiven & $\mathrm{mg} 1$ & & 0.2 & - \\
\hline 2 & Besi & $m=1$ & 0,795 & 0.3 & $x$ \\
\hline 3. & Resababan & 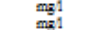 & 12 & $\begin{array}{l}500 \\
250\end{array}$ & $x$ \\
\hline 5. & Mangas & $m a 1$ & 0,0399 & 0.4 & $v$ \\
\hline${ }_{7}^{6}$ & Seng & $m=1$ & & $\begin{array}{l}6,-8,3,3 \\
3\end{array}$ & \\
\hline 8. & Salfat & $m=1$ & 41 & 250 & $\mathrm{v}$ \\
\hline 9. & Tembaga & $m=1$ & 0.0304 & 2. & v \\
\hline 1. & Amsonia & $\operatorname{mg}_{m=1}$ & 0.015 & $\frac{1,5}{3}$ & v \\
\hline 12 & Narat & $\operatorname{mgg} 1$ & 3,7 & 50 & $\mathrm{v}$ \\
\hline 13. & Frossido & $\operatorname{mg} 1$ & 0.14 & is & v \\
\hline 14. & Toal fromiven & $m=1$ & 0,0026 & 0,05 & \\
\hline$\frac{1}{1}$ & EColi & jemish pes 100 & 0 & 0 & $v$ \\
\hline 2 & $\begin{array}{l}\text { Toal Baberi } \\
\text { Kalformm }\end{array}$ & 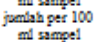 & 0 & 0 & $\mathrm{v}$ \\
\hline IV. & $\begin{array}{l}\text { Boban OrganY } \\
\text { Deserjen }\end{array}$ & $\underset{m a 1}{m_{m} 1}$ & 0.02 & $\begin{array}{c}10 \\
0.05\end{array}$ & $v$ \\
\hline
\end{tabular}

Kerangan :

$\mathrm{v}=$ masih dibawah batas kadar maksimum yang diperbolehkan

$\mathrm{x}=$ diatas batas kadar maksimum yang diperbolehkan

Pada tabel diatas dapat dilihat bahwa parameter-parameter yang terkandung dalam air hasil produksi (pengolahan) berada dibawah kadar maksimum yang diperbolehkan PerMenKes No.492 Tahun 2010. Air produksi ini kemudian bisa didistribusikan ke pelanggan air bersih.

\subsection{ANALISIS PENGARUH BIAYA PRODUKSI DAN PENJUALAN AIR BERSIH TERHADAP LABA KOTOR}

4.7.1 Laporan Laba Rugi

Laporan laba rugi IPA PJ merupakan laporan laba rugi komparatif ddisajikan dengan beberapa tahap.

Berikut adalah laporan laba rugi IPA Pejompongan untuk Tahun 2010 dan 2011 yang disajikan dalam bentuk laporan laba rugi komparatif. Tabel 4.22 Laporan Laba rugi Periode 2010-2011

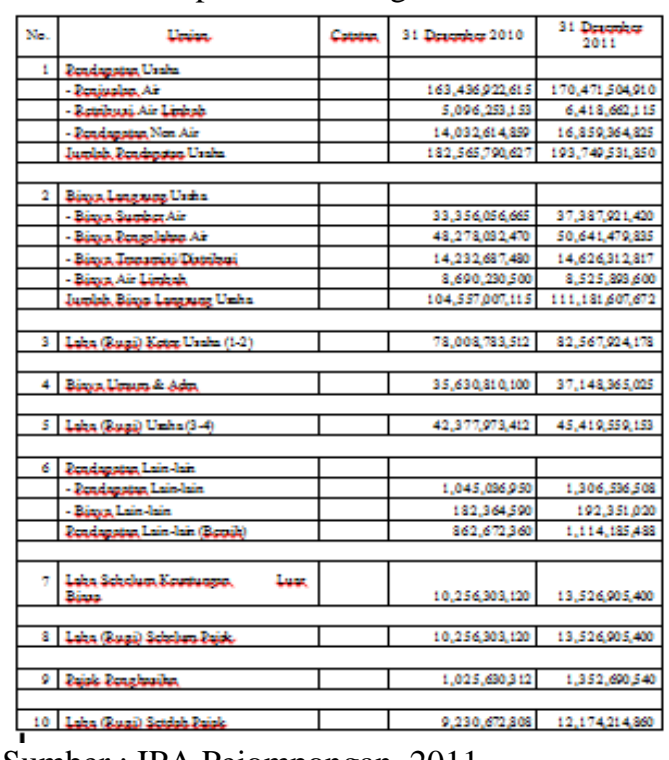

Sumber : IPA Pejompongan, 2011

Tabel 4.23 Jumlah Biaya Produksi Air Bersih Periode 2010/2011 


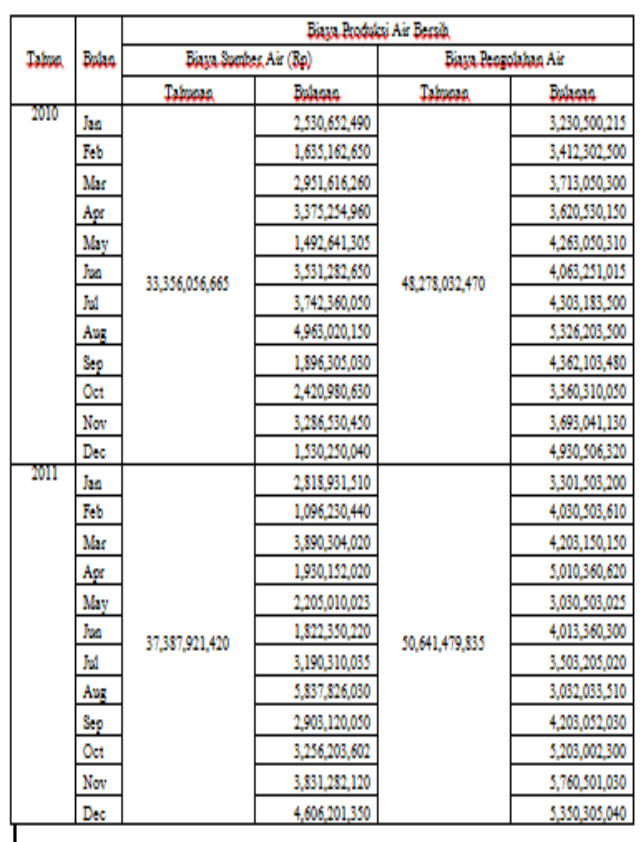

Sumber : IPA Pejompongan, 2011

Tabel 4.24 Jumlah Penjualan Air Bersih IPA Periode $2010 / 2011$

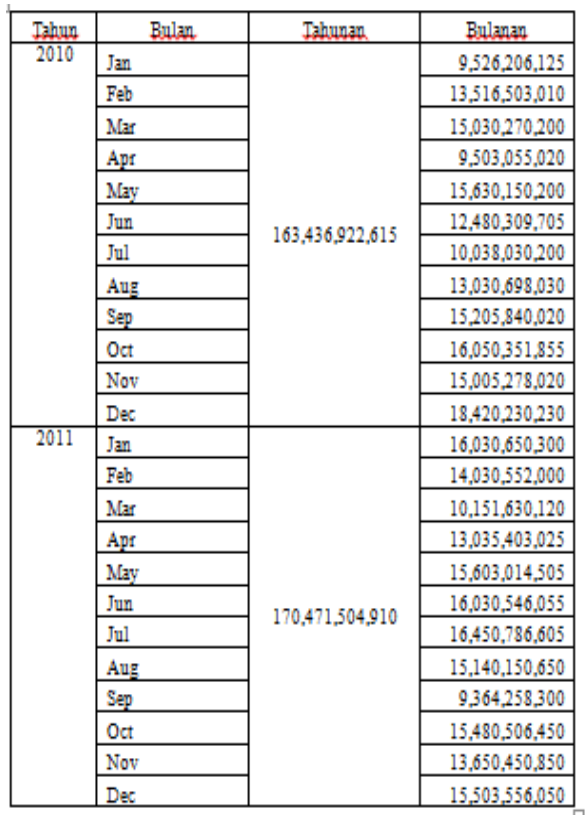

Tabel 4.25 Jumlah Laba Kotor IPA

Pejompongan Periode 2010 - 2011

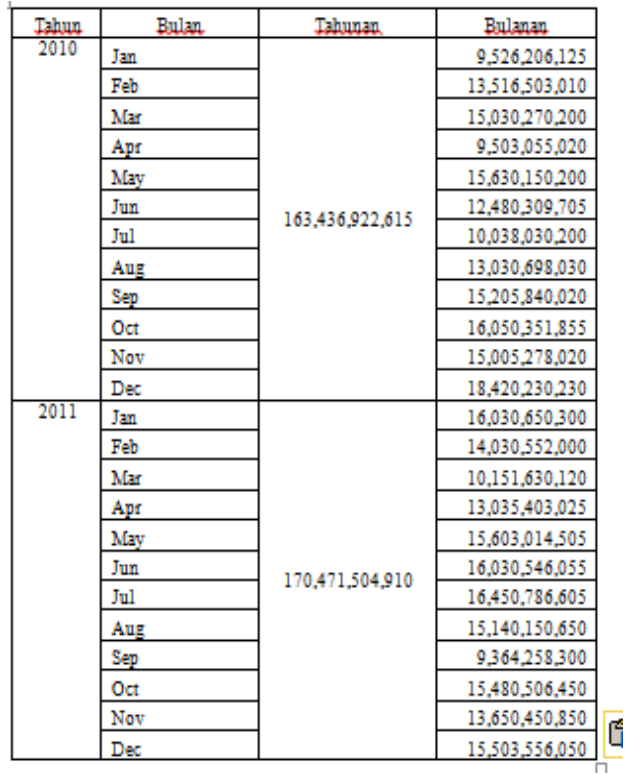

Sumber : IPA Pejompongan, 2011

\subsubsection{Hasil Estimasi Model}

Estimasi model diperoleh dari analisis regresi linier berganda. Analisis regresi merupakan suatu metode yang digunakan untuk menganalisa hubungan regresi merupakan suatu metode yang digunakan untuk menganalisa hubungan antar variabel.

Tabel 4.26 Print Out Coefficient Program SPSS (Statistical Product and Service Solution) Versi 16.0

Coefficients

\begin{tabular}{|c|c|c|c|c|c|}
\hline \multirow[b]{2}{*}{ Model } & \multicolumn{4}{|c|}{ Unstanderdized Coefficiant Standardized Coefficiants } & \multirow[b]{2}{*}{$t$ Sig. } \\
\hline & B & Std. Error & Beta & & \\
\hline 1) (Constant) & $-3.947 \mathrm{Eg}$ & $4.563 \mathrm{Eg}$ & & & 046.927 \\
\hline$B S A B$ & .1 .203 & .170 & & & \\
\hline$B P A B$ & $\cdot 1.639$ & .247 & & .4 & 6.636 .001 \\
\hline$P A B$ & 1.109 & .378 & & .25 & .933 .008 \\
\hline
\end{tabular}

a. Dependent Variabel : Laba Kotor (LK)

Nilai konstanta dan koefisien regresi untuk masing-masing variabel bebas ditunjukkan oleh angka pada kolom unstandardized coefficient bagian B.

\subsubsection{Analisis Koefisien Determinasi}

Tabel 4.27 Print Out Model Summary Model Summary ${ }^{\mathrm{b}}$

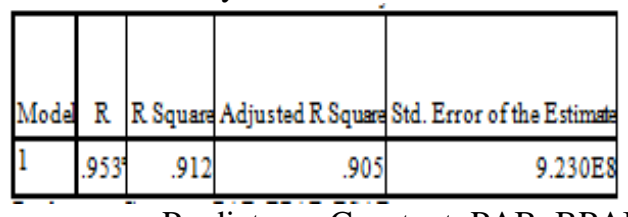

a. Predictors : Constant, PAB, BPAB, BSAB

b. Dependent Variabel: LK 


\subsubsection{Pengujian Hipotesis Parsial (Uji t} Statistik)

a. Variabel Biaya Sumber Air Bersih

Prosedur pengujian :

1. Formulasi Hipotesis

$\mathrm{H}_{0}: \beta_{\mathrm{x} 1}=0$, artinya tidak ada pengaruh biaya sumber air bersih terhadap laba

kotor.

$\mathrm{H}_{0}: \beta_{\mathrm{x} 1} \neq 0$, artinya ada pengaruh biaya sumber air bersih terhadap laba kotor.

5. Kesimpulan

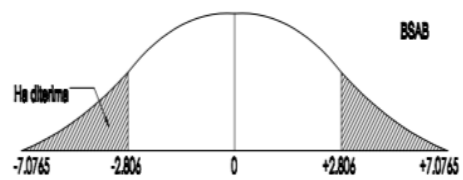

Gambar 4.8 Hasil Pengujian Hipotesis Partial Pada Biaya Sumber Air Bersih

Dikarenakan $\mathrm{t}$ hitung lebih kecil daripada $\mathrm{t}$ table $(-7,0765<-2,086)$, maka keputusan yang diambil adalah menolak $\mathrm{H}_{0}$ yang berarti menerima $\mathrm{H}_{\mathrm{a}}$ hal ini berarti variabel biaya sumber air bersih berpengaruh terhadap laba kotor.

\section{b. Variabel Biaya Pengolahan Air Bersih}

Prosedur pengujian :

1. Formulasi Hipotesis

$\mathrm{H}_{0}: \beta_{\mathrm{x} 2}=0$, artinya tidak ada pengaruh biaya sumber air bersih terhadap laba

kotor.

$\mathrm{H}_{0}: \beta_{\mathrm{x} 2} \neq 0$, artinya ada pengaruh

biaya sumber air bersih terhadap laba kotor.

5. Kesimpulan

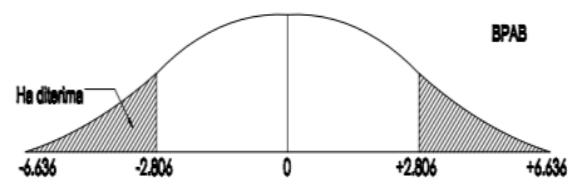

Gambar 4.9 Hasil Pengujian Hipotesis Partial Pada Biaya Pengolahan Air Bersih

\section{c. Variabel Penjualan Air Bersih}

Prosedur pengujian :

1. Formulasi Hipotesis

$\mathrm{H}_{0}: \beta_{\mathrm{x} 3}=0$, artinya tidak ada pengaruh biaya sumber air bersih terhadap laba

kotor.
$\mathrm{H}_{0}: \beta_{\mathrm{x} 3} \neq 0$, artinya ada pengaruh biaya sumber air bersih terhadap laba kotor.

5. Kesimpulan

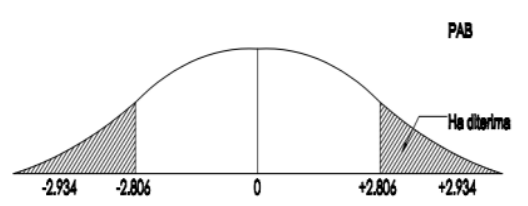

Gambar 4.10 Hasil Pengujian Hipotesis Partial Pada Penjualan Air Bersih

Dikarenakan $\mathrm{t}$ hitung lebih kecil daripada $\mathrm{t}$ table $(2,934>+2,086)$, maka keputusan yang diambil adalah menolak $\mathrm{H}_{0}$ yang berarti menerima $\mathrm{H}_{\mathrm{a}}$ hal ini berarti variabel penjualan air berpengaruh terhadap laba kotor.

\subsubsection{Pengujian Hipotesis Serentak (Uji F} Statistik)

Prosedur pengujian :

1. Formulasi Hipotesis

$\mathrm{H}_{0}: \beta_{\mathrm{x} 1}: \beta_{\mathrm{x} 2}: \beta_{\mathrm{x} 3}=0$, artinya biaya sumber air bersih, biaya pengolahan air bersih

dan penjualan air bersih, secara bersama-sama tidak berpengaruh terhadap laba

kotor.

$\mathrm{H}_{0}: \beta_{\mathrm{x} 1}: \beta_{\mathrm{x} 2}: \beta_{\mathrm{x} 3} \neq 0$, artinya biaya sumber air bersih, biaya pengolahan air bersih dan penjualan air bersih, secara bersama-sama berpengaruh terhadap laba

kotor.

\section{Kesimpulan}

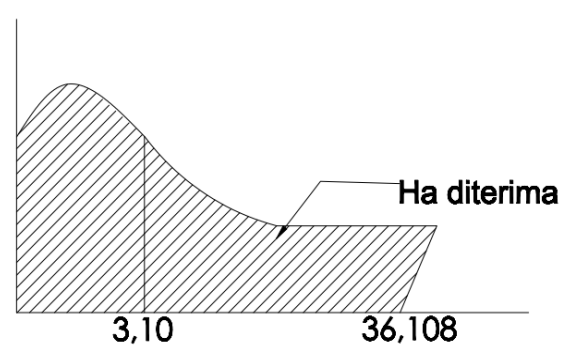

Gambar 4.11 Hasil Pengujian Hipotesis Serentak

Tabel 4.28 Print Out ANOVA 
ANOWA

\begin{tabular}{|c|c|c|c|c|c|}
\hline Model & Sum of Squaress & df & Magn Square & $\overline{\mathrm{F}}$ & Sig. \\
\hline Regression & $9.250 \mathrm{E} 18$ & 3 & $3.083 \mathrm{E} 19$ & \multirow[t]{3}{*}{63.619} & \multirow[t]{3}{*}{$.000^{\mathrm{s}}$} \\
\hline Residual & $1.704 E 19$ & 20 & 8.519817 & & \\
\hline Total & $2.629 \mathrm{E} 19$ & 23 & & & \\
\hline
\end{tabular}

a. Predictors: (Constrnt), PAB, BPAB,

$B S A B$ 
BAB 5

\section{KESIMPULAN DAN SARAN}

\subsection{KESIMPULAN}

Berdasarkan hasil penelitian yang telah dibahas sebelumnya, dapat ditarik kesimpulan sebagai berikut :

1. Kebutuhan air bersih untuk penduduk di wilayah UPP Pusat hingga tahun 2032 adalah 2.791,95 lt/dtk pada jam normal, $3.489,94 \mathrm{lt} / \mathrm{dtk}$ pada hari maks dan $5.583,90 \mathrm{lt} / \mathrm{dtk}$ pada jam puncak.

2. Hasil evaluasi kondisi eksisting unitunit instalasi sebagai berikut :

a. Gradien kecepatan, kondisi aliran dan waktu detensi unit koagulasi telah sesuai dengan kriteria desain 3 dari 4 sumber (Darmasetiwan (2001), SNI 67742008 dan Qasim (AWWA 2004))

b. Gradien kecepatan dan kondisi aliran unit flokulasi telah sesuai dengan kriteria desain 3 dari 4 sumber, namun waktu detensi hasil perhitungan belum sesuai dengan kriteria desain 3 sumber tersebut.

c. Unit sedimentasi yang berada di clarifier belum sesuai dengan kriteria desain baik itu untuk dimensi, kecepatan pada settler,surface loading rate maupun weir loading rate.

d. Luas permukaan dan jumlah unit filtrasi telah memenuhi kriteria desain namun kecepatan aliran pipa inlet/outlet dan kecepatan aliran pada saat normal/backwash belum memenuhi kriteria desain menurut Reynolds (1982) dan SNI 67742008.

e. Pada proses desinfektan telah sesuai dengan kriteria desain yang berlaku.

f. Bak reservoir telah sesuai dengan kriteria desain baikitu jumlah unit, kedalaman bak hingga tinggi jagaan. Namun waktu tinggal yang terlalu lama yang dapat berpengaruh terhadap kualitas air produksi.

3. Dari hasil analisis, ketersediaan air produksi IPA PJ I saat ini belum cukup untuk memenuhi kebutuhan air penduduk di wilayah UPP Pusat hingga tahun 2032. Adanya defisit debit air dapat dipenuhi dengan berbagai upaya antara lain dengan bantuan tambahan suplai air dari IPA PJ II yang memiliki kapasitas air produksi lebih besar.

4. Banyak parameter kualitas air baku yang didapatkan dari berbagai lokasi sumber air baku yang tidak sesuai dengan Peraturan Pemerintah No.82 Tahun 2001.

5. Secara garis besar, kualitas air produksi saat ini telah sesuai dengan Peraturan Menteri Kesehatan No.492/Menkes/Per/IV/2010 dan tergolong layak didistribusikan dan dikonsumsikan oleh penduduk.

6. Dari hasil analisis regresi yang dilakukan:

a. Biaya sumber air bersih berpengaruh negatif terhadap laba kotor. Jika biaya sumber air bersih mengalami kenaikan maka laba kotor akan mengalami penurunan, dan sebaliknya.

b. Biaya pengolahan air bersih juga berpengaruh negatif terhadap laba kotor. Jika biaya pengolahan air bersih mengalami kenaikan maka laba kotor akan mengalami penurunan, dan sebaliknya.

c. Hasil penjualan air bersih berpengaruh positif terhadap laba kotor. Jika penjualan air bersih mengalami peningkatan,maka pihak IPA PJ akan mendapatkan peningkatan pada laba kotor. 


\section{DAFTAR PUSTAKA}

\subsection{SARAN} menyarankan :

Dari hasil penelitian diatas, penulis

1. Untuk memenuhi kebutuhan air bersih untuk penduduk wilayah UPP Pusat perlu adanya perbaikan dan optimalisasi unit-unit instalasi pengolahan yang ada di IPA PJ yang disarankan dari hasil evaluasi, hal ini dapat menaikkan biaya pengolahan air.

2. Untuk mendapatkan kualitas air baku yang baik sesuai dengan standar peraturan, perlu adanya observasi lanjutan terhadap sumber air baku, hal ini dapat menaikkan biaya sumber air bersih.

3. Untuk meningkatkan keuntungan (laba kotor) atau menutupi 'pembengkakan' biaya sumber air dan pengolahan air, pihak pengelola dapat memperolehnya dengan memberikan kepuasan pada penduduk/pelanggan dengan kualitas air produksi yang layak konsumsi dan sesuai dengan standar peraturan.

4. Perlu dibuat sistem dan prosedur yang baku didalam pengoperasian IPA Pejompongan untuk menjaga konsistensi kuantitas, kualitas dan kontinuitas produksi

5. Perlu adanya peningkatan keahlian dan pengetahuan pada human resources untuk mengoptimalkan kinerja dalam proses instalasi.

6. Untuk penelitian selanjutnya, perlu variabel bebas yang digunakan dapat lebih dari 3variabel yang mempengaruhi laba kotor dengan jumlah data penelitian yang lebih banyak sehingga hasil yang diperoleh lebih baik.

7. Penulis menyarankan agar tidak menjadikan analisa penelitian ini sebagai satu-satunya alat analisis dalam usaha untuk meningkatkan laba kotor perusahaan, sebaiknya dilakukan pula analisis dengan model analisis lainnya.
Amalia, Rizka, dkk. Evaluasi dan Desain Unit Pengolahan Air Minum Dalam Rangka Peningkatan Kapasitas Instalasi di PT.Krakatau Tirta Industri, Cilegon Banten. Institut Pertanian Bogor. Bogor

AWWA. 1998. Water Treatment Plant And Design. New York: Mc Graw Hill Companies, Inc

Darmasetiawan, Martin. 2001. Teori dan Perencanan Instalasi Pengolahan Air. Bandung: Yayasan Suryono.

Darmasetiawan. 2004. Teori Dan Perencanaan Instalasi Pengolahan Air. Jakarta: Ekamitra Engineering.

Degreemont. 1970. Water Treatment Handbook, 5th ed. New York: John Willey \& sons.

Delphos, JP, Werner, GM. 2004. Mixing, Coagulation and Flocculation. Didalam: American Water Works Association/American Society of Civil Engineers. Water Treatment Plant Design fourth edition. Amerika Serikat: McGrawHill.

Fajri Arifiani, Nur, dkk. 2007. Evaluasi Desain Instalasi Pengolahan Air PDAM Ibu Kota Kecamatan Prambanan Kabupaten Klaten. Universitas Diponegoro. Semarang

Hartono, Joko, dkk. 2010. Evaluasi dan Optimalisasi Kinerja Instalasi Pengolahan Air Minum Citayam, PDAM Tirta Kahuripan Terhadap Pertumbuhan Penduduk Kota Depok. Universitas Indonesia. Depok

Ikatan Akuntansi Indonesia. 2004. Standar Akutansi Keuangan. Salemba Empat. Jakarta

Kawamura, S. 1991. Integrated Design of Water Treatment Facilities. John Wiley and Sons Inc. Canada. USA

Munawir, S, 2001. Analisis Laporan Keuangan. Cetakan Kedua belas. Yogyakarta 
Qasim, SR, Motley, EM,Zhu, G. 2000. Water Works Engineering Planning Design \& Operation. Amerika Serikat: Prentice-Hall

Reynolds, T.D and Richards, P.A 1996. Unit Operation and Proccess In Enviromental Engineering, Second Edition. PWS Publishing Company. USA

Reynolds. 1982. Unit Operations and Processes in Environmental Engineering. California

Schultz, C.R.and Okun, D.A. 1992. Surface Water Treatment For Communities in Developing Countries. New York. USA

Setyandito, Iki, dkk. 2006. Rencana Tindak (Action Plan) Dan AnalisaPenyediaan Air Bersih Di Propinsi Nusa Tenggara Barat.Universitas Mataram. Nusa Tenggara Barat

Sutrisno. 2000. Akuntansi Biaya. Penerbit Ekonisia. Yogyakarta

Syarifudin, Adib. Xxx. Analisis Kebutuhan dan Ketersediaan Air Bersih Unit Sumberlawang PDAM Sragen. Sragen.

Wahyuni saputri, Afrike. 2011. Evaluasi Instalasi Pengolahan Air Minum (IPA) Babakan PDAM Tirta Kerta Raharja Kota

Tanggerang. Universitas Indonesia. Depok

Wulan dani, Surya. 2006. Analisis Pengaruh Biaya Produksi dan Penjualan Air Bersih Terhadap Laba Kotor Pada PDAM Tirtanadi. Universitas Sumatera Utara. Medan

Palyja annual report 2010 dan 2011 